\title{
REVISION OF THE GENUS BATHYSCIDIUS JEANNEL, 1910 (COLEOPTERA: LEIODIDAE: CHOLEVINAE: LEPTODIRINI), WITH A DESCRIPTION OF A NEW SUBGENUS AND THREE NEW SPECIES FROM CROATIA AND MONTENEGRO
}

\author{
Slavko Polak ${ }^{1, *}$ \& Branko Jalžić ${ }^{2}$ \\ ${ }^{1}$ Notranjska museum Postojna, Kolodvorska cesta 3, SI-6230 Postojna, Slovenia \\ ${ }^{2}$ Croatian Biospeleological Society, Demetrova 1, HR-10000 Zagreb, Croatia
}

Polak, S. \& Jalžić, B.: Revision of the genus Bathyscidius Jeannel, 1910 (Coleoptera: Leiodidae: Cholevinae: Leptodirini), with a description of a new subgenus and three new species from Croatia and Montenegro. Nat. Croat., Vol. 28, No. 2., 359-402, 2019, Zagreb.

The genus Bathyscidius is, according to the body size, one of the smallest leptodirines. Six species, one of them including two subspecies, have been described to date. This study has undertaken a taxonomical revision of the genus Bathyscidius s. str. Existing species are re-described, supported with detailed morphometry and, for the first time, with the description of male and female internal morphological characters. Three newly discovered species B. mljetensis, B. komajiensis and B. orjensis are described; one subspecies $B$. t. fallaciosus is elevated to species rank and one of the existing species B. remyi is synonymized. For the two geographically isolated species, B. rambouseki and B. tomoricensis, a new subgenus, Ionobathyscidius, is established.

Key words: Leptodirini, Bathyscidius, Ionobathyscidius, systematics, revision, new species, Dinaric Karst

Polak, S. \& Jalžić, B.: Revizija roda Bathyscidius Jeannel, 1910 (Coleoptera: Leiodidae: Cholevinae: Leptodirini), s opisom novog podroda i tri nove vrste iz Hrvatske i Crne Gore. Nat. Croat., Vol. 28, No. 2., 359-402, 2019, Zagreb.

Rod Bathyscidius je, s obzirom na veličinu tijela, jedan od najmanjih leptodirina. Dosad je opisano šest vrsta, jedna od njih s dvije podvrste. Rad donosi taksonomsku reviziju roda Bathyscidius $\mathrm{s}$. str. Postojeće vrste su ponovno opisane, s detaljnom morfometrijom i po prvi put s opisom nekih morfoloških karakteristika mužjaka i ženki. Opisane su tri nove vrste: B. mljetensis, $B$. komajiensis and $B$. orjensis, jedna podvrsta, B. t. fallaciosus, podignuta je na rang vrste, a jedna je vrsta, B. remyi, sinonimizirana. Za dvije geografski izolirane vrste, B. rambouseki i $B$. tomoricensis ustanovljen je novi podrod Ionobathyscidius.

Key words: Leptodirini, Bathyscidius, Ionobathyscidius, sistematika, revizija, nove vrste, dinarski krš

\section{INTRODUCTION}

The large leiodid beetle tribe Leptodirini (Leiodidae: Cholevinae) is known for its numerous subterranean taxa. The group has a distribution centered on the northern part of the Mediterranean basin (Newton, 1998; Perreau, 2000, 2004, 2015; Fresneda et al., 2011), the greatest diversity being in the Dinaric karst

\footnotetext{
* corresponding author: slavko.polak@notranjski-muzej.si
} 
(Pretner, 1968; 1973; 1977), where some unusual adaptations to subterranean life have evolved. Besides the large, highly troglomorphic taxa with prolonged body and appendages (i.e. Leptodirus Schmidt, 1832; Anthroherpon Reitter, 1889; Hadesia Jeannel, 1911), there are also small and spherical, so-called bathyscioid, and mostly edaphic taxa in the area. Unlike the larger and gracile subterranean taxa, which were recognized as separate genera at first glance, the small edaphic bathyscioid species were usually put into the commonly distributed genera Bathyscia Schiødte, 1848 or Bathysciola Jeannel, 1910, which served as a dumping place. It was only after subsequent detailed scientific work that some new genera were established for numerous small bathyscioid species.

Specimens of one of the smallest leptodirini collected in a cave near the village Janjina on Pelješac peninsula in Dalmatia (Croatia) were described by Apfenbeck (1905) as Bathyscia (s. str.) tristicula. Later on, MüLLER (1910) described a separate subspecies Bathyscia tristicula fallaciosa from a cave at the source of the Ombla River near Dubrovnik. In one of his first revisions of leptodirines, JEANNEL (1910) established a new genus Bathyscidius for this species, and grammatically changed the species name to $B$. tristiculus with two recognized subspecies. The third subspecies, B. tristiculus tomoricensis, was found later on Mt Tomor in southern Albania, and was described by Müller (1922). This subspecies was elevated to species rank by JeAnnel (1924). After that, two more species of this genus were described; B. rambouseki from Galičica Mountain above Ohrid (Northern Macedonia) described by KNIRsch (1931) and B. remyi, from Bracanovića pećina on Bjelasica Mountain (Montenegro) described by JeAnNeL (1934). Later on Karaman (1964) described Bathyscidius (Pseudobathyscidius) serbicus from the surroundings of Zaječar in Eastern Serbia and established a monotypical subgenus Pseudobathyscidius. The subgenus Pseudobathyscidius was elevated by Guéorguiev (1976) to the genus rank. Giachino (2005) described a new significantly larger species (2.07-2.66 mm) Bathyscidius comottiorum, from the cave Shpella e Burmit in Kosovo. He synonymized the genus Pseudobathyscidius (Karaman 1964) with Bathyscidius Jeannel, 1910 in the same paper. Later PerreAu (2008) established a new genus Pavicevicia for the species Bathyscidius comottiorum (Gaichino, 2005) and described an additional species, P. pretneri, from Kosovo. In the same contribution (Perreau, 2008), the author discussed the hardly justified synonymy of Pseudobathyscidius with Bathyscidius suggested by Giachino (2005), and proposed that Pseudobathyscidius should have the status of separate genus again.

Our recent cave explorations in Croatia, Montenegro and Northern Macedonia resulted in collection of individuals from the type localities and some new locations that enable us to review the group of species. The study focused on the revision of the genus Bathyscidius s. str. with re-descriptions of existing species. Descriptions are supported with detailed morphometry and, for the first time, with illustrations of some internal morphological characters for males and females. 


\section{MATERIALS AND METHODS}

Specimen collected and material studied. Over a period of 15 years, we collected representatives of the most described species of Bathyscidius from the type localities in caves, superficial subterranean habitats and leaf litter in Dalmatia (Croatia), Montenegro and Northern Macedonia. Depending on their habitat requirements, some of the taxa were collected by visual inspection, by deployment of baited pitfall traps, and in the case of edaphobionts by soil and leaf litter sifting. For the morphological analyses, the specimens were preserved in $10 \%$ vinegar and $40 \%$ or $50 \%$ ethanol. Additionally, some specimens were preserved in $96 \%$ ethanol for forthcoming molecular analyses. The fieldwork was undertaken with permits from the nature conservation authorities of Croatia (Ministarstvo zaštite okoliša i energetike; No. URBROJ: 517-07-1-1-1-16-4) and Montenegro (Agencija za zaštitu životne sredine; No. 02/UPI-341/6, No. 02/UPI-740/7). Since the search for topotype specimens of B. tomoricensis near Berat, Albania, was not successful, the small series of type and topotype specimens, preserved in the Natural History Museum of Trieste (NHMT), was loaned for the needs of the study. The type locality of $B$. tristicula, the small cave near Janjina on Pelješac, Croatia, was not found despite intensive efforts by the members of Croatian Biospeleological Society. However, they did find Bathyscidius specimens in three additional caves on the Pelješac peninsula. The two paratype specimens of B. tristicula from Janjina, preserved in Egon Pretner's Collection, which is now deposited in the Slovenian Museum of Natural History (PMSL) Ljubljana, have been dissected and studied. Small leptodirini specimens resembling Bathyscidius have been collected in Velika Bracanovića pećina and in the nearby cave Županska pećina on Mt Bjelasica, Montenegro. The holotype of Bathyscidius remyi has been checked and studied in the Collection of the Entomological Department of the National Museum of Natural History (MNHN) in Paris (France).

Morphological analyses. Specimens were dry card mounted, partly dissected, measured and in the case of the type series, designated as type specimens. The detail-studied specimens, originally placed in $96 \%$ ethanol, were dissected after maceration in $10 \% \mathrm{KOH}$ at room temperature for 12 hours, washed in pure water and dehydrated with ethanol. The body lengths of dry prepared and glued specimens were measured under the stereomicroscope. All other measurements, including pronotum and elytra, were measured as dissected body parts on microscope slides, and measured under the microscope. Photographs were taken using a Leica MZ7.5 stereomicroscope (0.63-5.0 x 10 magnifications) and a Euromex microscope ME2665 (10 x 4, $10 \times 10$ and 10 x 40 magnifications). Taxonomically informative body parts (antenna, appendages, metatergal apparatus, metendosternite and genital parts) were separated and immersed in glycerine or Solakryl BMX media on classical microscope slides. Dissected genital parts were preserved by being immersed in Solakryl BMX media on a transparent label, and were pinned under the Holotype and some of the Paratype specimens. Photographs of dissected specimens were made using a Nikon Coolpix 4500 
digital camera and measured with the freely available Image J software (accessible at https://imagej.nih.gov/ij/). Digital microscope images were additionally edited using Adobe Photoshop and CorelDraw.

\section{Abbreviations - Institutes and Collections}

Specimens are deposited in collections identified by the following acronyms:

NMPO: Notranjska museum Postojna, Postojna (Slovenia), CNHM: Croatian Natural History Museum, Zagreb (Croatia), NHMM: Zoological collection of Natural History Museum of Montenegro, Podgorica (Montenegro), HBSD: Croatian Biospeleological Society, Zagreb (Croatia), NHMT: Natural History Museum of Trieste, (Italy), PMSL: Egon Pretner Collection of the Slovenian Museum of Natural History, Ljubljana (Slovenia), MNHN: National Museum of Natural History, Paris (France).

- Measurements (in mm):

BL: Total body length measured from the anterior apex of head (in natural position, head not extended) to apex of elytra; AL: Antenna total length, measured without the first antennomere stalk; AL/PL: Antennal elongation index = antennal length / pronotum length; AmL: Lengths of antennomeres (1-11); AmW: Width of antennomeres (1-11); AmL/W: Antennal index (1-11) $=$ antennomere length / antennomere width; AL/AmL: Antennal percentage index (1-11, in \%); PL: Pronotum maximal length; PW: Pronotum maximal width; EL: Elytra maximal length; EW: Elytra maximal width; PL/W: Ratio width / length of pronotum; EL/W: Ratio width / length of elytra; PtarL: Protarsomere (total) length; PtarW: Protarsomeres wid th; PtibL: Protibia length; PtibW: Protibia max width; AedL: Aedeagus length; AedMaxW: Aedeagus median lobe maximal width; AedMinW: Aedeagus median lobe minimal width; AedL/AedMaxW: Aedeagus index1 = length of aedeagus / maximal median lobe width; BlamL: Aedeagus basal lamina maximal length; BlamW: Aedeagus basal lamina maximal width; AedL/BlamL: Aedeagus basal lamina length index = aedeagus length / basal lamina length; BlamL/BlamW: Aedeagus basal lamina index = basal lamina length / basal lamina width; $\mathbf{M}$ : mean number or average; $\mathbf{N}$ : number of measured samples; Max: maximal; Min: minimal; HT: Holotype; PT: Paratype.

\section{TAXONOMY}

\section{Genus Bathyscidius Jeannel, 1910}

Bathyscidius Jeannel, 1910: Arch. Zool. expe. gén., 45 (1): 15

Type species: Bathyscidius tristiculus (Apfelbeck, 1905)

Bathyscidius Jeannel, 1910: JeAnNEL, 1911, Arch. Zoll. exp. gén., 47 (1): 415.

Bathyscia (Bathyscidius) tristicula Apfelbeck: Jeannel, 1914, Coleopterum catalogus pars 60: 16. Bathyscidius Jeannel: 1910: Müller, 1917, Mathem.-naturw. Klasse, Abt 1,126 (8) 32, 37.

Bathyscidius Jeannel, 1910: JeAnnel, 1924, Arch. Zool. expe. Gén., 63 (1): 268-269.

Bathyscidius Jeannel, 1910: Laneyrie, R, 1967, Ann. De Spéléologie. 22 (3), 595, 611.

Bathyscidius Jeannel, 1910: Pretner, 1968, Catalogus Faunae Jugoslaviae III. (6), 20.

Bathyscidius Jeannel, 1910: Guéorguiev, 1974, C. R. Acad. Bul. Sci. 27(6): 839-842.

Bathyscidius Jeannel, 1910: GuéorguIEv, 1976, Dissertationes SAZU, 14(4): 14, 48

Bathyscidius Jeannel, 1910: Newton, 1998, Atti Museo Reg. di Scienze Natur., Torino, 127.

Bathyscidius Jeannel, 1910: Perreau, 2000, Mémoires de la SEF, 4: 193.

Bathyscidius Jeannel, 1910: Perreau, 2004, Catalogue of Palaearctic Coleoptera Vol 2: 153.

Bathyscidius Jeannel, 1910: Perreau, 2015, Catalogue of Palaearctic Coleoptera Vol 2: 180-290. Bathyscidius Jeannel, 1910: Huaváč et al., 2017, The Subterranean Beetles of the Balkan Peninsula, 100.

Bathyscidius Jeannel, 1910: Perreau, 2019, Zootaxa 4590(3): 367-381.

\section{Redescription}

Cavernicolous or endogeic, apterous and small-sized Leptodirini 1.27-1.80 mm in length. Habitus: Bathyscioid, prolonged elliptic (Fig. 1), strongly convex (Fig. 
2). Depigmented, color yellowish brown to reddish brown (Figs. 15, 16, 45, 46).

Head: Anophthalmus and retractile. Occipital carina obliterated, not present but with evident straight border between the glabrous and pubescent part on the neck. Pubescence on the head set up randomly without order. Mandible short with 1-2 small dents. The $4^{\text {th }}$ segment of maxillary palp shorter than the $3^{\text {rd }}$, small and conical. Antenna inserted on the median third of the head, relatively short. Ratio $\mathrm{AL} / \mathrm{PL}$ is $0.98-1.43$ depending on the species and sex. Antennomeres, especially the terminal ones, dorso-ventrally flattened. The $2^{\text {nd }}$ antennomere significantly longer than the first in all species. The $7^{\text {th }}$ Antennomere larger with a welldeveloped Hamman organ. Antennomeres 8, 9 and 10 transverse, significantly wider than long or oval to slightly longer than wide, depending on the species. The $11^{\text {th }}$ antennomere is the longest, 1.5-2.0 times longer than wide (Figs. 79-92).

Pronotum: Strongly convex (Fig. 2), wider than long, with regularly rounded lateral edges, not sinuated before the base, widest at base, equally as wide as or slightly wider than elytra. (Figs. 1, 17, 18, 31, 32, 47, 48). Prosternum ventral face almost glabrous, dorsal face strongly pubescent with uniform short and recumbent pubescence set up without order, aligned in a transversal row only at the very basal edge.

Elytra: Elongated-oval, largely rounded at the basal apex, with maximum width (EW) on the anterior part of elytra, without sutural carina (Figs. 1, 19, 20, 33, $34,49,50)$. Pubescence on the elytra aligned in transversal striae along the whole elytral length, and in slightly undulating lateral rows. Transparent microscopic observation reveals the presence of large circular papillae on basal and lateral part of elytra. Scutellum widely triangular, pubescent on the posterior side only.

Thorax: Ventral face almost glabrous, shiny, with reticulate and leathery aspect. Mesocoxal cavities not confluent. Metacoxae separated with narrow and forked metasternal intercoxal apophysis (Fig. 3). Mesosternal carina well developed, elevated, moderately thick, not lamellar, flattened on the ventral edge and with a few, recumbent, backward oriented bristles. In lateral view highly elevated, widely rounded on anterior side, on posterior side the sharp beak of carina extended over the metasternum, almost reaching the metasternal intercoxal apophysis (Figs. 3, 21, 35, 51). Metendosternite (Crowson's organ) "V" shaped with dorsal arms longer than stalk and wide extended apical muscle disc. (Fig. 11) Metatergal apparatus with lateral processes strongly reduced, lanceolate and with moderate long posterior process (Figs. 9, 10).

Legs: Moderately short and robust. Protarsi with four not dilated segments in both sexes. First three protarsomeres of approximately the same length (first slightly longer than the $2^{\text {nd }}$ and $3^{\text {rd }}$ ) and the $4^{\text {th }}$ significantly longer. Mesotarsi and metatarsi with five not dilated segments (Figs. 7, 8). Claws simple, strong and sharp, empodium with one bifurcated seta. Protibias flattened, pubescent and with numerous spines towards the distal half (Figs. 5, 6). On the external lateral and apical side with the row of flattened spines of equal length forming a comb (pecten) stretching for approximately one to two apical thirds of the tibial length. On internal apical side with one smaller and one large and strong polident (5-toothed) spurs. Mesotibiae and metatibiae cylindrical with numerous spines towards the distal half and periapical ring of spines of unequal length and two large, strong 5-toothed spurs on the internal apical side (Figs. 7, 8). Metatibiae 
with some additional stronger spines on the external-lateral side. Femora with reticulated aspect, almost glabrous or sparsely-haired according to the species.

Male genitalia: Aedeagus relatively small, elongated and more or less straight in dorsal and lateral view. Median lobe apex in dorsal view flattened, moderately rounded or pointed, according to the species, without or with a sharp beak. Inner sac without visible sclerotized structures. Basal lamina almost parallel with median lobe (Figs. 65-78) in some species relatively long (Figs. 73-78), simple rounded, not invaginated backwards on its apical part.

Parameres straight, parallel with median lobe, shorter than median lobe. Paramere apex armed with three erected setae of similar sizes and lengths. Setae insertion according to the species, one apical straight long seta and two subapical long setae oriented towards the median lobe (Fig. 24, 25, 38, 39, 54, 55, 61, 65$72,77,78$ ) or three apical (subapical) erected long setae as in B. rambouseki and B. tomoricensis (Figs. 62, 73-76). Male genital segment partly reduced, on dorsal (tergal) side forming a hood (Fig. 13, 40, 56). In dorsal view para-ring-like (Figs. 12, 26). External edge on tergal and sternal side rounded, slightly acute, without hairs on tergal external side. On ventral (sternal) side, the internal lobe is hyaline (Fig. 12). In a lateral view, with a significant hood on the tergal part, prolonged to long and narrow dorso-lateral processes (Fig.13).

Female genitalia: Female ventrite VIII (Fig. 14, 27, 41, 57) strongly haired on proximal part with anterior stout or slim apophysis of medium length. Urite IX (genital segment-ovipositor) with stylomeres relatively short, wide and bulky with straight outer and significantly convex inner edge (Figs. 28, 42, 58, 63) or basally concave outer and moderately convex inner edge as in B. rambouseki (Fig. $64)$ and $B$. tomoricensis where stylomeres are longer and narrower. Sub-gonocoxite with one stylus, gonocoxite with one basal, one lateral and two subapical styles, apical gonostylus is the longest. Spermatheca (Figs. 29, 43, 59) sack-like or sausagelike, curved, uniformly and weakly sclerotized, rounded distally. Hyaline gland attached to the spermathecal duct at the proximal part of spermatheca.

Bathyscidius tristiculus (Apfelbeck, 1905)

Bathyscia (s. str.) tristicula Apfelbeck, 1905: Glas. Zemaljskog Muz. Bosni i Herceg., 17: 247. lct : In einer unbenannte Höhle bei Janjina, Halbinsel Sabioncello (Pelješac), Dalmatien, Croatia. Bathyscia (s. str.) tristicula Apfelbeck, 1907: Wiss. Mitt. Bosnien Herceg., 10: 642. (Second publication).

Bathyscina tristiculus Apfelb. JeAnnel, 1908: Arch. Zool. exp. Gén., 4e série, 8: 299.

Bathyscidius tristiculus Apfelbeck: Jeannel, 1910: Arch. Zoll. exp. Gén. 45 (1): 37.

Bathyscidius tristiculus Apfelbeck: JeAnnel, 1911: Arch. Zoll. exp. Gén, 47 (1): 415.

Bathyscia (Bathyscidius) tristicula Apfelbeck: JeAnnel, 1914: Coleopterum catalogus pars 60: 16. Bathyscidius tristiculus. Apfb: Müller, 1917: Mathem.-naturw. Klasse, Abt 1,126 (8) 32, 37, 39.

Bathyscidius tristiculus. Apfb: Müller, 1922: Estr. dal Boll. Soc. ent. ital., 54:89-90.

Bathyscidius tristiculus subsp. tristiculus Apfelbeck: 1907: JeAnnel, 1924, Arch. Zool. expe. Gén., 63 (1): 269.

Bathyscidius tristiculus Apf.: LAneyrie, R., 1967, Ann. De Spéléologie. 22 (3), 611.

Bathyscidius tristiculus tristiculus (Apfelbeck, 1907): Pretner, 1968: Catalogus Faunae Jug. III. (6), 20.

Bathyscidius tristiculus Apfelbeck, 1907: Newton, 1998: Atti Museo Reg. di Scienze Natur., Torino, 127.

Bathyscidius tristiculus tristiculus (Apfelbeck, 1905): Perreau, 2000: Mem. Sef, 4.: 193. 
Bathyscidius tristiculus tristiculus (Apfelbeck, 1905): Perreau, 2004: Catalogue of Palaearctic Coleoptera. Vol 2:153.

Bathyscidius tristiculus: Perreau, 2008, Inst. Nat. prot. Serbia, Monogr., 22: 179-180. DC PG ST

Bathyscidius tristiculus tristiculus (Apfelbeck, 1905): Perreau, 2015: Catalogue of Palaearctic Coleoptera: 180-290.

Bathyscidius tristiculus tristiculus Apfelbeck, 1906: Hlaváč, P., Perreau, M., Č́erlík, D., 2017: Czhec Univ. of Life Csci, Pague, 100

Bathyscidius tristiculus Jeannel, 1910: Perreau, 2019, Zootaxa 4590 (3): 367-381.

Victor Apfelbeck (ApFelBeck, 1905) described the species as Bathyscia (s. str.) tristicula based on specimens collected by himself in a small cave, without a name near the village of Janjina in the Pelješac peninsula, Dalmatia, Croatia. Original diagnose is (in Latin): "B. Lesinae affinis, corpore minus convexo et magis elongato, elytris subtilius transversim ruguloso-punctatis, striis suturalibus nullis, antennis multo longioribus, earum articulis $4^{\circ}, 5^{\circ}$ et $6^{\circ}$ latitudine duplo longiorbius, $9^{\circ}$ et $10^{\circ}$ haud transversis, articulo ultimo multo magis elongate, et in $\circ$ tarsis anticis simplicibus, haud dilatatis divergit. + Tarsus anticus inconspicue quinque-articulatus, articulis omnibus simplicibus. In paeninsulae Sabioncello antro hucusque innominato prope Janjina a me detecta".

In the original description, Apfelbeck added (translated from Bosnian): "According to the tarsi, the species is similar to the species B. Lesinae Reitt. (Phaneropella lesinae today), but differs from it due to the lack of sutural carina, longer antenna according to the similar body size, being less gracile, with a somehow prolonged habitus and transversal punctuation of elytra; from the species B. Erberi Schauf. (Pholeuonella erberi today) and B. curzolensis Ganglb (Dalmatiola curzolensis today) it significantly differs in the simple shape of protarsi, compared to complex in last two species. From B. erberi besides this, it differs in the different shape of antenna, and from B. curzolensis due to reduction of pubescence on elytra.

First and second antenna articles are widened, prolonged, second slightly longer than first and three times longer than wide. Third and following articles half-width of second, third almost three times longer than wide. Articles 4 to 6 almost of same length and two times longer than wide. Article 6 widened at the apex, 7 enlarged, almost twice as long as wide, (8 -not written) rounded and not transverse, slightly narrower but much shorter than 7; 9 and 10 are gradually widened but not transversal; 9 is slightly longer than wide; 10 slightly longer than 9; last segment almost as long as 9 and 10 together. I collected it in Dalmatia on the Pelješac peninsula, in a small, unnamed cave near Janjina."

Material Examined: Pelješac (Croatia), Janjina, (no other data on label), Apfelbeck, $2 \widehat{\jmath} \hat{\jmath}$-Paratypes (PMSL); Pelješac (Croatia), Duba Pelješka, Tomasova spilja, 6 đิ $\widehat{~ \& ~} 7$ 우, 05.04.2019, B. Jalžić leg. (CNHM, HBSD, NMPO); Pelješac (Croatia), Duba Pelješka, Pleće, Spilja Rupine, 6 đ̋ \& \& 3 우, 27.03.2019, B. Jalžić leg. (CNHM, HBSD, NMPO); Pelješac (Croatia), Ston, Vukasi dolnje, Ponikve, Špilja Bijelo jezero, $1 \widehat{\jmath} \widehat{\jmath} \& 3 q+$, 29.03.2019, B. Jalžić leg. (CNHM, HBSD, NMPO).

REDESCRIPTION

Size: Total body length (BL): 1.36-1.61 mm (M=1.47, N=8, PT: 1.44, $1.61 \mathrm{~mm})$ in $\delta^{\lambda} \delta^{\lambda}$ and $1.48-1.80 \mathrm{~mm}(\mathrm{M}=1.59, \mathrm{~N}=10)$ in $\circ$ q. Colour: Reddish-brown, antenna 
and legs slightly paler. Antenna: Antenna (Figs. 79, 80) total length (AL): 0.590$0.720 \mathrm{~mm}(\mathrm{M}=0.646, \mathrm{~N}=10, \mathrm{PT}: 0.63,0.69 \mathrm{~mm})$ in $\hat{\sigma}^{\lambda}$ and $0.531-0.716 \mathrm{~mm}(\mathrm{M}=$

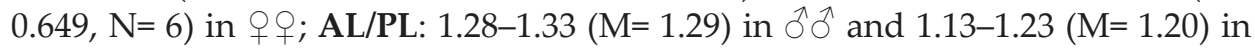
오오.

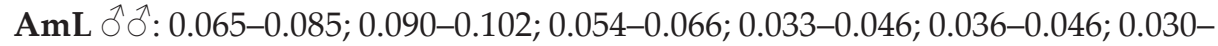
$0.039 ; 0.049-0.059 ; 0.031-0.041 ; 0.045-0.059 ; 0.045-0.061 ; 0.099-0.121$ (N = 10; PT: $0.078 ; 0.102 ; 0.059 ; 0.041 ; 0.043 ; 0.035 ; 0.057 ; 0.036 ; 0.047 ; 0.059 ; 0.110)$;

AmL + Q $: 0.063-0.087 ; 0.093-0.120 ; 0.046-0.075 ; 0.031-0.048 ; 0.034-0.045 ; 0.028-$ $0.045 ; 0.044-0.067 ; 0.025-0.037 ; 0.040-0.056 ; 0.040-0.056 ; 0.085-0.115(\mathrm{~N}=6)$.

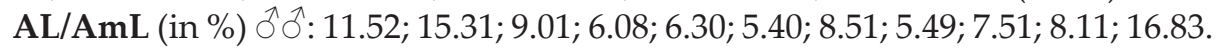

AL/AmL (in \%) $q$ + $: 11.76 ; 15.95 ; 9.43 ; 6.14 ; 6.27 ; 5.86 ; 8.76 ; 4.93 ; 7.42 ; 7.53 ; 15.95$.

AmL/W ồ $2.00 ; 3.05 ; 2.69 ; 1.78 ; 1.66 ; 1.30 ; 1.47 ; 1.02 ; 1.08 ; 1.02 ; 1.82$.

AmL/W $\circ \circ: 1.97 ; 3.09 ; 2.94 ; 1.73 ; 1.72 ; 1.32 ; 1.39 ; 1.27 ; 0.94 ; 0.78 ; 1.58$.

Pronotum: Transverse, strongly concave with regularly rounded lateral edges, maximum width on posterior edge. PL: $0.464-0.535 \mathrm{~mm}(\mathrm{M}=0.500, \mathrm{~N}=7)$ in

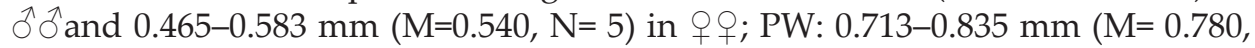
$\mathrm{N}=7)$ in $\widehat{\partial} \hat{\partial}$ and $0.829-0.930 \mathrm{~mm}(\mathrm{M}=0.920, \mathrm{~N}=7)$ in 우; PL/PW: 0.65-0.64 (M= $0.64)$ in $\widehat{\partial} \hat{o}$ and $0.56-0.64(\mathrm{M}=0.59)$ in 90 .

Thorax: Mesosternal carina well developed, elevated, moderately thick, on ventral edge flattened not lanceolate, extended over the metasternum, almost reaching the metasternal intercoxal apophysis. Metendosternite as in other species of the genus. Metatergal apparatus with lateral processes strongly reduced and with moderate long apophysis as in other species of the genus.

Elytra: Elytra elongated-oval with maximum width on anterior part of elytra. Strongly pubescent with uniform short and decumbent pubescence inserted in strong lateral rows - transversal striae on complete elytra surface, without sutural carina. EL: 0933-1.082 $\mathrm{mm}(\mathrm{M}=0.970, \mathrm{~N}=5)$ in $\hat{\partial} \widehat{\partial}$ and 0.931-1.143 $\mathrm{mm}(\mathrm{M}=1.051$,

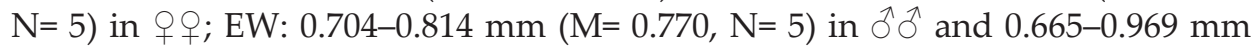
$(\mathrm{M}=0.844, \mathrm{~N}=5)$ in $\bigcirc$ + ; ratio EL/EW: $1.21-1.33(\mathrm{M}=1.26)$ in $\widehat{\jmath} \widehat{\jmath}$ and 1.18-1.66 $(\mathrm{M}=$ 1.25) in 우요.

Legs: Short and stout as in other species of the genus (Figs. 5-8). Male and

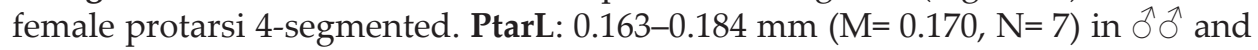
0.163-0.207 mm (M=0.179, N= 5) in 우; PtarW: 0.018-0.024 mm (M=0.020, N=7) in $\widehat{\partial} \hat{\partial} \&$ \& 9 , not dilated at both sexes; PtibL: $0.233-0.266 \mathrm{~mm}(\mathrm{M}=0.250, \mathrm{~N}=7)$ in

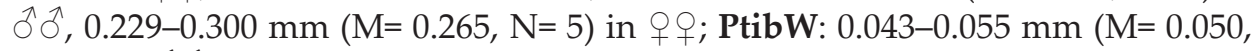
$\mathrm{N}=7)$ in $\widehat{\partial}, 0.045-0.050 \mathrm{~mm}(\mathrm{M}=0.049, \mathrm{~N}=5)$ in $q$ 우. Lateral side of protibia in both sexes armed with distinct comb of flat spines and two apical polident spurs as in other species of the genus (Figs. 5-6).

Male genitalia: Aedeagus elongated, extremely small, AedL: 0.312-0.353 mm $(\mathrm{M}=0.340, \mathrm{~N}=7$, PT: 0.336, $0.339 \mathrm{~mm}$ ) long. In dorsal view (Fig. 65) median lobe straight and slender, AedMaxW: at the apical third 0.044-0.054 mm (M=0.050, N= 7, PT: 0.047, 0.049) wide; AedMinW: at the basal third 0.026-0.039 mm (M=0.030, $\mathrm{N}=7$, PT: 0.036, 0.038) wide. Apex of median lobe moderately rounded, not pointed (Fig. 24). Inner sac without visible sclerotized structures. AedL/AedMaxW: 6.47.5. Basal lamina parallel with median lobe, relatively short compared to other 
species of the genus. BlamL: 0.058-0.078 mm (M=0.070 PT: 0.064, $0.068 \mathrm{~mm}, \mathrm{~N}=10)$ long; BlamW: 0.057-0.078 mm (M=0.070, N= 5 PT: 0.072, $0.072 \mathrm{~mm})$ wide. AedL/ BlamL: 4.6-5.6; BlamL/BlamW: 0.9-1.2. Aedeagus in lateral view (Fig. 66) almost straight, only slightly curved at the apical part. Parameres straight, parallel with median lobe, shorter than median lobe, with one apical and two subapical long setae, similar in size and length, protruding over the median lobe apex (Figs. 61, 65). Male genital segment in dorsal view ring-like, annular, in lateral view with significant hood on the side, similar to other species of the genus (Figs. 12, 13).

Female genitalia: Female ventrite VII strongly haired on proximal part with anterior stout or slim apophysis of medium length, like other species of the genus (Fig. 14, 27, 41, 57). Urite IX (genital segment-ovipositor) characteristic for the subgenus Bathyscidus s. str., stylomeres relatively short, wide with straight outer and convex inner edge (Fig. 63). Sub-gonocoxite with one stylus, gonocoxite with one basal, one lateral and two subapical styles, gonostylus with one longest stylus. Spermatheca sack-like or sausage-like, curved, uniformly and weakly sclerotized, rounded distally, as in other species of the genus (Figs. 29, 43, 59). Hyaline gland attached to the spermathecal duct at the proximal part of spermatheca.

\section{Differential diagnosis.}

Bathyscidius tristiculus differs from other Bathyscidius species by shape of aedeagus median lobe apex, which is not pointed as in $B$. rambouseki and $B$. tomoricensis (Figs. 62, 73-76) but elliptically rounded (Figs. 61, 65). B. orjensis has an extremely and for the genus unusually wide median lobe (Figs. 77, 78). B. fallaciosus and B. komajiensis have a relatively shorter aedeagus with significantly widened median lobes on apical third (Figs. 69-72). B. tristiculus has an aedeagus similar to B. mljetensis sp.n., which has the aedeagus slightly narrower $(67,68)$. The latter two species can be easily distinguished by significantdifferences in antenna length. B. tristiculus has relatively longer antenna (Figs. 79, 80), total length (AL): $0.590-0.720 \mathrm{~mm}$ in $\widehat{\partial} \hat{\sigma}$ and $0.531-0.716 \mathrm{~mm}$ in $q$ 우 ; as compared to B. mljetensis

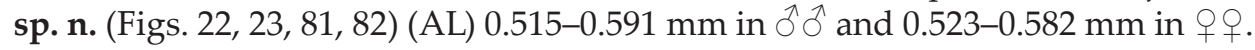

Distribution. The species is known from its type locality, the cave near Janjina, Pelješac (Croatia), according to the original description. Despite significant efforts of Croatian speleobiologists, the type locality has not yet been found and identified. It seems as if, some decades ago, the cave was destroyed or filled up during construction works. Recently, in 2019, populations that fit with the type specimens were found in the Pelješac peninsula in Tomasova spilja and Spila Rupine near Duba Pelješka approximately $20 \mathrm{~km}$ west of Janjina and in špilja Bijelo jezero near the village of Vukasi, Ponikve, approximately $12 \mathrm{~km}$ of Janjina (Fig. 95).

Ecology. Nothing is known about how the specimen was collected at the type locality except that the cave was small. The species was recently found at the bottom end? of the small, 41 meter long cave Tomasova spilja, which was once used as a shelter for domestic animals. The temperature $10.0^{\circ} \mathrm{C}$ and humidity $94 \%$ were measured on 05.04.2019 in the main chamber of the cave. The specimens were mostly collected in the soil and organic debris under the rocks, close to the 
entrance. In Spilja Rupine the specimens were collected near the entrance of the main chamber $(66 \times 34 \times 14 \mathrm{~m})$ among the rock debris and sinter deposits on the steep cave slope. In the cave the temperature of $9.1^{\circ} \mathrm{C}$ and $90 \%$ air humidity were measured on 24.04.2019. The finding place was usually covered with bat guano deposits. In the cave Bijelo jezero (21 m long) the specimens were collected under rock debris and soil in the main cave chamber. In the cave the temperature of $12.4^{\circ} \mathrm{C}$ was measured on 29.03.2019.

Bathyscidius mljetensis Polak \& Jalžić sp. n.

Figs. 5-9, 15-29, 63, 64, 77, 78

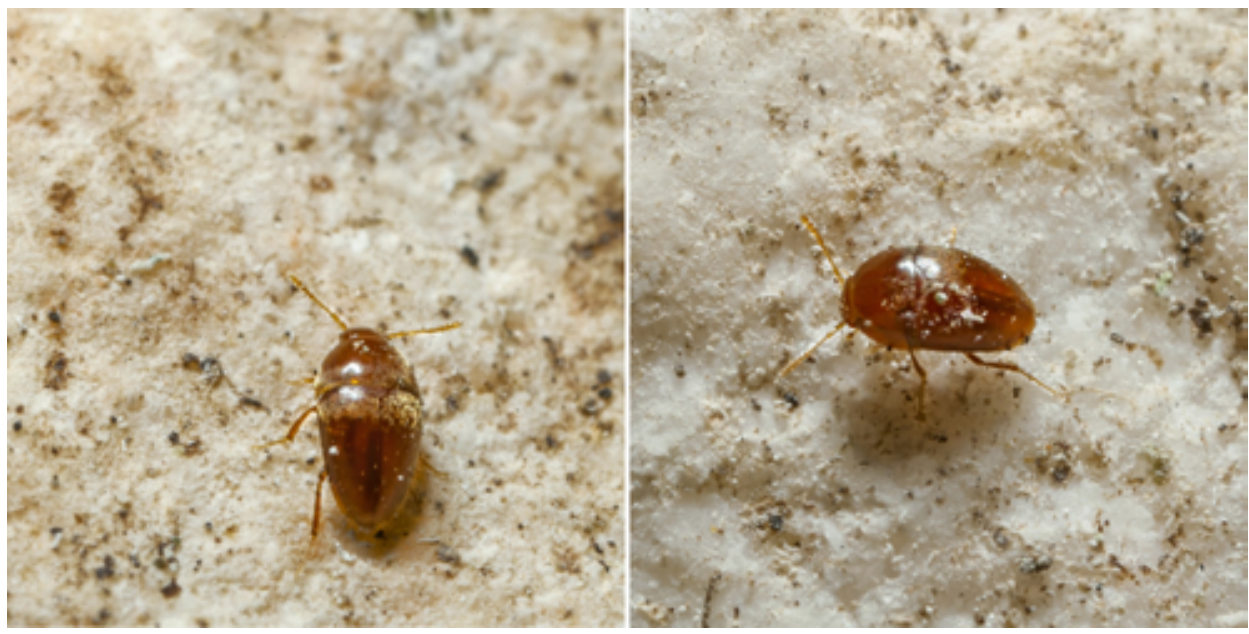

Figs. 15-16. Bathyscidius mljetensis sp. n. in its natural habitat in the type locality Jama na Žutim kokom. (Photo: T. Cuković)

Type locality: Jama na Žutim kokom, (Synonyms: Vickova jama, Jama za Žutim kokom), situated near the village of Maranovići, Blato, Island of Mljet in Southern Dalmatia (Croatia) (Figs. 30, 95).

Material ExAmined: specimens as declared in type series. Additional material: Otok Mljet, Ostaševica (Jama na Žutim kokom), 26.03.1993, 1 đ̊ , Rađa T. leg., (NMPO); Polače, Vriješće, Špilja kod vrha Spile, 1 đ̃, 06.04.2015, Malenica M. leg., (HBSD).

DESCRIPTION.

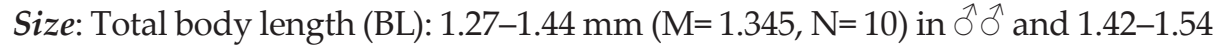
$\mathrm{mm}(\mathrm{M}=1.48, \mathrm{~N}=10)$ in $9+$. Colour: Yellowish to yellowish brown, antenna and legs slightly paler (Figs. 15, 16). Antenna: (Figs. 22, 23, 81, 82) Antenna total length (AL): 0.515-0.591 mm (M=0.553, $\mathrm{N}=8)$ in 00 and 0.523-0.582 $\mathrm{mm}(\mathrm{M}=0.554, \mathrm{~N}=6)$ in 우우 AL/PL: 1.23-1.27 (M=1.25) in $\delta^{\top} \delta^{\lambda}$ and 1.19-1.21 $(\mathrm{M}=1.19)$ in 우우.

AmL ô ô: 0.061-0.069; 0.078-0.099; 0.040-0.55; 0.030-0.035; 0.032-0.037; 0.029$0.034 ; 0.041-0.049 ; 0.026-0.32 ; 0.033-0.041 ; 0.037-0.045 ; 0.084-0.103(\mathrm{~N}=8)$.

AmL 우: 0.061-0.074; 0.087-0.099; 0.044-0.54;0.032-0.037;0.034-0.040;0.028$0.035 ; 0.047-0.052 ; 0.026-0.031 ; 0.035-0.040 ; 0.037-0.039 ; 0.087-0.091(\mathrm{~N}=6)$.

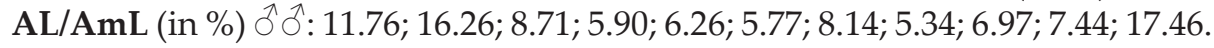
AL/AmL (in \%) 우: $12.54 ; 16.87 ; 8.57 ; 6.07 ; 6.58 ; 5.80 ; 8.90 ; 5.08 ; 6.79 ; 7.83 ; 15.97$. 


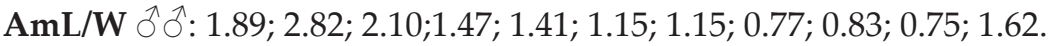

AmL/W $\circ$ : $: 1.85 ; 2.97 ; 2.30 ; 1.62 ; 1.54 ; 1.27 ; 1.33 ; 0.77 ; 0.78 ; 0.69 ; 1.50$.

Pronotum: Transverse, strongly concave with regularly rounded lateral edges, maximum width on posterior edge (Figs. 17, 18). Dorsal face strongly pubescent with uniform short and decumbent pubescence, without order. PL: 0.420-0.466 $\mathrm{mm}(\mathrm{M}=0.442, \mathrm{~N}=7)$ in $\widehat{\partial}$ and $0.440-0.481 \mathrm{~mm}(\mathrm{M}=0.464, \mathrm{~N}=6)$ in $\bigcirc$; $\mathrm{PW}$ :

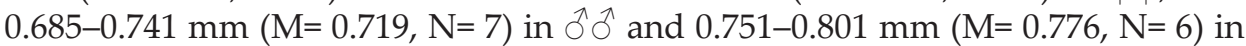

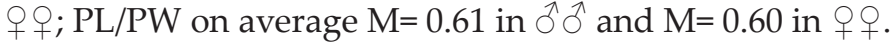

Thorax: Mesosternal carina well developed, elevated, moderately thick, on ventral edge flattened not lanceolate, extended over the metasternum, almost reaching the metasternal intercoxal apophysis (Fig. 21). Metendosternite as in other species of the genus. Metatergal apparatus with lateral processes strongly reduced and with moderate long apophysis as in other species of the genus.

Elytra: Elytra elongated-oval with maximum width on anterior part of elytra (Figs. 19, 20). Strongly pubescent with uniform short and decumbent pubescence inserted in strong lateral rows - transversal striae on complete elytra surface, without sutural carina. EL: 0.875.-0.951 $\mathrm{mm}(\mathrm{M}=0.918, \mathrm{~N}=7)$ in $\bar{\partial} \hat{\gamma}$ and $0.954-$ $1.043 \mathrm{~mm}(\mathrm{M}=0.988, \mathrm{~N}=6$ in $q$ q $; \mathrm{EW}: 0.752-0.760 \mathrm{~mm}(\mathrm{M}=0.756, \mathrm{~N}=7)$ in $\widehat{\partial} \hat{\sigma}$ and $0.762-0.824 \mathrm{~mm}(\mathrm{M}=0.782, \mathrm{~N}=5)$ in 9 + ; ratio $\mathrm{EL} / \mathrm{EW}: 1.21-1.24(\mathrm{M}=1.21, \mathrm{~N}=5)$ in 하 and $1.25-1.28(\mathrm{M}=1.26, \mathrm{~N}=5)$ in 우우.

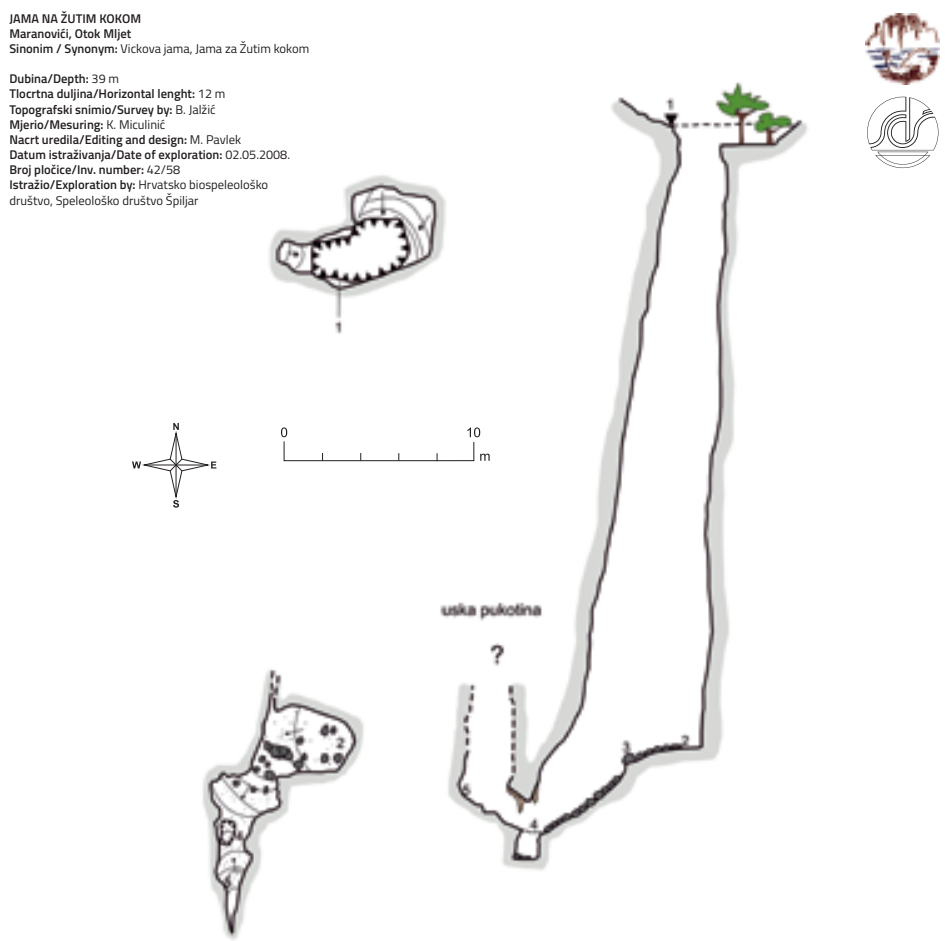

Fig. 30 Speleological survey of the cave Jama na Žutim kokom, the type locality of Bathyscidius mljetensis sp. $\mathbf{n}$. 
Legs: Short and stout as in other species of the genus (Figs. 5-8). Male and female protarsi 4-segmented. PtarL: 0.176-0.196 (M=0.185, $\mathrm{N}=5) \mathrm{mm}$ in $\hat{\partial} \hat{o}^{\lambda}$ and 0.170-0.190 ( $\mathrm{M}=0.182, \mathrm{~N}=5) \mathrm{mm}$ in 우; PtarW: 0.019-0.024 (M=0.020, N=5) mm

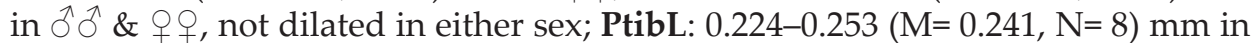

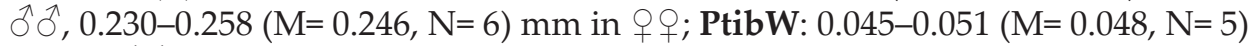
$\mathrm{mm}$ in ${ }^{\lambda} \delta^{\lambda}, 0.046-0.049(\mathrm{M}=0.047, \mathrm{~N}=5) \mathrm{mm}$ in + 우. Lateral side of protibia in both sexes armed with distinct comb of flat spines and two apical polident spur (Figs. 5-6) as in other species of the genus.

Male genitalia: Aedeagus elongated, extremely small, AedL: 0.309-0.347 (M= $0.321, \mathrm{~N}=7$ ) $\mathrm{mm}$ long. In dorsal view (Figs. 24, 67) median lobe straight and slender, AedMaxW; at the apical third 0.038-0.046 ( $M=0.041, N=5)$; AedMinW; at the basal third 0.027-0.035 (M=0.031, N=5) mm wide. Apex of median lobe moderately rounded, not pointed (Fig. 24, 67). Inner sac without visible sclerotized structures. AedL/AedMaxW: 7.4-8.3. Basal lamina parallel with median lobe, relatively short compared to other species of the genus (Figs. 24, 25, 67, 68). BlamL: 0.064-0.090 ( $\mathrm{M}=0.080, \mathrm{~N}=5) \mathrm{mm}$ long, BlamW: 0.058-0.085 ( $\mathrm{M}=0.072, \mathrm{~N}=$ 5) $\mathrm{mm}$ wide. AedL/BlamL: 3.6-4.9; BlamL/BlamW: 0.8-1.5. Aedeagus in lateral view (Fig. 25, 68) almost straight. Parameres straight, parallel with median lobe, shorter than median lobe, with one apical and two subapical long setae, similar in size and length, protruding over median lobe apex (Fig. 24, 25, 67, 68). Male genital segment (Fig. 26) in dorsal view ring-like, annular, in lateral view with significant hood on the side, similar to other species of the genus.

Female genitalia: Female ventrite VIII (Fig. 27) strongly haired on proximal part with anterior stout or slim apophysis of medium length. Urite IX characteristic for the genus, stylomeres relatively short, wide with straight outer and convex inner edge (Fig. 28). Sub-gonocoxite with one stylus, gonocoxite with one basal, one lateral and two subapical styles, gonostylus with one longest stylus. Spermatheca (Fig. 29) sack-like or sausage-like, curved, uniformly and weakly sclerotized, rounded distally. Hyaline gland attached to the spermathecal duct at the proximal part of spermatheca.

Differential diagnosis. Bathyscidius mljetensis sp. n. differs from other Bathyscidius species by the shape of the aedeagus median lobe apex, which is not pointed as in B. rambouseki and B. tomoricensis (Figs. 73, 75) but elliptically rounded. $B$. orjensis have extreme and for genus unusually wide median lobe (Fig. 77). B. fallaciosus and B. komajiensis have a relatively shorter aedeagus with is significantly widened median lobes on apical third (Figs. 69, 71). B. mljetensis sp. $\mathbf{n}$. has an aedeagus similar to that of $B$. tristiculus, which has a slightly wider aedeagus. The latter two species can be easily distinguished by significantly differences in antenna length (Figs. 22, 23, 81, 82). B. mljetensis sp. $\mathbf{n}$. has total antenna length (AL): $0.515-0.591 \mathrm{~mm}$ in $\hat{\sigma} \hat{~}$ and $0.523-0.582 \mathrm{~mm}$ in $q+$, compared to B. tristiculus that has antenna longer $0.590-0.720 \mathrm{~mm}$ in ${ }^{\lambda} \delta^{\lambda}$ and $0.531-0.716$ $\mathrm{mm}$ in 우오.

Etymology. The species epithet is a toponym derived from the name of the island of Mljet.

Distribution. The new species is known only from its type locality, the cave "Jama na Žutim kokom" on Mljet island, Croatia. One studied male from Špilja 
kod vrha Spile near Polače on the western part of the island fits with B. mljetensis too. Since it has slightly shorter terminal antennomeres, and a single specimen is known so far, the species determination of this specimen is only provisional. So far we consider Bathyscidius mljetensis to be the only species of the genus on the island of Mljet.

Ecology. Specimens of B. mljetensis sp. n. were collected in the 39 meter deep cave named Jama na Žutim kokom. In the cave, some other troglobiontic animals were discovered (Ćurćić et al., 2012a). The specimens were collected on the bottom of the pit among the rock debris filled with soil and leaf litter from the surface. Sunlight periodically penetrates from the entrance to the bottom of the cave. The temperature on the collecting site measured on 22.10 .2015 was $12.6^{\circ} \mathrm{C}$ and the air humidity was $95.8 \%$.

Type series. Holotype $\hat{\sigma}$, glued to a white card, pinned dry, aedeagus dissected and preserved immersed in Solakryl BMX media on a transparent label pinned below the specimen, labeled: HOLOTYPE | Bathyscidius mljetensis sp. n. $\stackrel{0}{\mid}$ | Polak \& Jalžić det., [rectangular red label, printed]. Second label: CROATIA: Otok Mljet, Maranovići, Jama na Žutim kokom, 2.9.2011, Jalžić, B. leg. [rectangular white label, printed], - (CNHM).

Paratypes: PARATYPE | Bathyscidius mljetensis sp. n. | Polak \& Jalžić det. [rectangular yellow label, printed]. Second label: [rectangular white label, printed], specimen glued to white card, pinned dry, dissected genital parts and some body parts preserved immersed in Solakryl BMX on a transparent label, pinned below the specimens : $4 \hat{\partial} \hat{\partial}$ and 2 $\odot$, , 2.9.2011, Jalžić, B. leg., same locality as the holotype

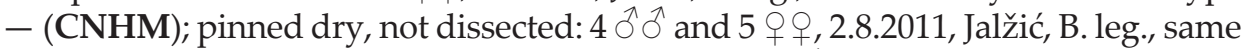
localityas the holotype; pinned dry, not dissected: 1 đ and 1 o, 2.5.2011, Jalžić, B. leg., same locality as the holotype, pinned dry, not dissected:- (HBSD).

Specimens dissected (body parts, aedeagus, genital segments, protarsi, and

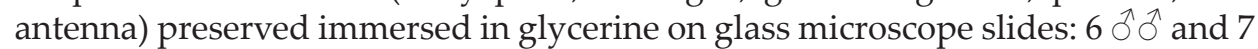
우우, 2.8.2011, Jalžić, B. leg., same locality as the holotype - (NMPO).

Bathyscidius fallaciosus (Müller, 1910) status nov.

Bathyscia tristicula fallaciosa Müller, Zool. Anz., 36 (8/9): 184.

lct : Höhle oberhalb der Omblaquelle bei Ragusa (Dubrovnik), Dalmatien, Croatia.

Bathyscidius tristiculus subsp fallaciosus J. Müller 1910: JeAnnel, 1911, Arch. Zoll. exp. Gén, 47 (1): 415 .

Bathyscia (Bathyscidius) tristicula subsp. fallaciosa J. Müller: Jeannel, 1914, Coleopterum catalogus pars 60: 16 .

Bathyscidius tristiculus fallaciosus: Müller 1917, Mathem.-naturw. Klasse, Abt 1,126 (8) 32, 37.

Bathyscidius tristiculus subsp fallaciosus J. Müller 1910: Estr. dal Boll. Soc. ent. ital., 54:89-90.

Bathyscidius tristiculus subsp. fallaciosus J. Müller, 1910: Jeannel, 1924, Arch. Zool. expe. Gén., 63 (1): 269.

Bathyscidius tristiculus fallaciosus Müller: Winkler, 1925, Koleopterol. Rundsch., 11 (5-6): 141.

Bathyscidius tristiculus fallaciosus Müll.: Laneyrie, R., 1967, Ann. De Spéléologie. 22 (3), 611.

Bathyscidius tristiculus fallaciosus (J. Müller 1910): Pretner, 1968: Catalogus Faunae Jug. III. (6), 20.

Bathyscidius tristiculus fallaciosus Müller 1910: Perreau, 2000: Mem. Sef, 4.: 193.

Bathyscidius tristiculus fallaciosus Müller 1910: Perreau, 2004: Catalogue of Palaearctic Coleoptera. Vol 2:153. 
Bathyscidius tristiculus fallaciosus Müller 1910: Perreau, 2015: Catalogue of Palaearctic Coleoptera: $180-290$.

Bathyscidius tristiculus fallaciosus Müller 1910: Hlaváč, P., Perreau, M., Čeplík, D., 2017: Czhec Univ. of Life Csci, Pague, 100.

Type locality. Vilina špilja - izvor Omble (Ozımec et al., 2015).(Synonyms: Vilin stan, Vilina kuća, Vilina pećina iznad izvora Omble, Vilinska špilja, Höhle von Vilina Kučina, Quelle der Rijeka Dubrovačka bei Dubrovnik, Ombla; Omblaquelle bei Dubrovnik, Rijeka Dubrovačka-Quellen, Vilina špilja - Ombla izvor sustav) near Dubrovnik in Southern Dalmatia (Croatia) (Fig. 95).

Joseph Müller (MüLler, 1910) described a subspecies on the basis of the specimens collected by H.F. Neumann in 1909 in the Cave above Ombla Spring in Dubrovnik, Dalmatia, Croatia.

The original description (translated from German) is as follows: "From the typ. tristicula Apfb. from Sabbioncello it differs by constantly different shape of antenna, but we have to understand this probably only as a geographical race.

All the antennomers shorter and broader than in the typical form, viewed from the broad side, the antennomers 4-7 appear barely longer than wide, the eighth and ninth distinctly transverse, and the tenth even wider than long. At the typical tristicula, the antennomers 4-7 are prolonged, the eighth, ninth and tenth are not or slightly wider than long.

Due to the less developed antenna construction, especially of its last article, this Bath. can easily be confused with Bath. Erberi (Pholeuonella erberi today), and only the simple 4-segmented $\hat{\partial}$ protarsi enable reliable distinguish from it. Location: Cave above the Ombla Spring near Ragusa. Collected by Mr. Engineer H. F. Neumann (1909)."

Material Examined: Dalmatia (Croatia), Rijeka Dubrovačka, Vilin stan, 9

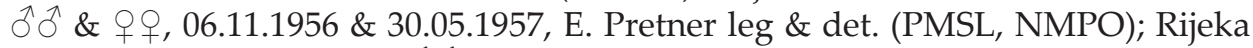

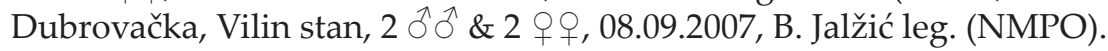

DESCRIPTION.

Size: Total body length (BL): $1.46-1.55 \mathrm{~mm}(\mathrm{M}=1.48, \mathrm{~N}=3)$ in $\widehat{\jmath}$ and 1.55-1.64 $\mathrm{mm}(\mathrm{M}=1.62, \mathrm{~N}=3)$ in 90 . Colour: Yellowish to reddish brown, antenna and legs slightly paler. Antenna: (Figs. 79, 80) Antenna total length (AL): 0.576-0.589 $\mathrm{mm}(\mathrm{M}=0.582, \mathrm{~N}=3)$ in $\widehat{\partial}$ and $0.585-0.602 \mathrm{~mm}(\mathrm{M}=0.590, \mathrm{~N}=3)$ in $\bigcirc$ + $;$ AL/PL:

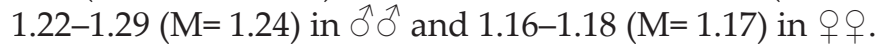

AmL ồ ô: $0.063-0.063 ; 0.098-0.103 ; 0.043-0.051 ; 0.032-0.032 ; 0.033-0.037 ; 0.034-$ $0.034 ; 0.049-0.051 ; 0.027-0.030 ; 0.040-0.043 ; 0.045-0.053 ; 0.098-0.103(\mathrm{~N}=3)$.

AmL $\circ$ 우 $0.070-0.073 ; 0.100-0.106 ; 0.044-0.053 ; 0.032-0.034 ; 0.034-0.039 ; 0.033-$ $0.035 ; 0.050-0.052 ; 0.027-0.031 ; 0.040-0.042 ; 0.043-0.046 ; 0.093-0.102(\mathrm{~N}=3)$.

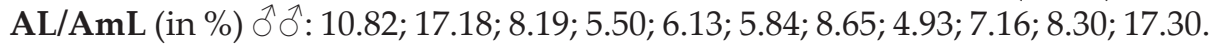

AL/AmL (in \%) 우: $12.16 ; 17.42 ; 8.26 ; 5.59 ; 6.23 ; 5.72 ; 8.69 ; 4.96 ; 6.91 ; 7.63 ; 16.44$.

AmL/W đ̂े: $1.97 ; 2.73 ; 1.93 ; 1.35 ; 1.37 ; 1.20 ; 1.28 ; 0.77 ; 0.92 ; 0.87 ; 1.60$.

AmL/W $\circ \circ: 1.95 ; 3.02 ; 2.24 ; 1.55 ; 1.52 ; 1.31 ; 1.36 ; 0.79 ; 0.86 ; 0.85 ; 1.76$.

Pronotum: As in genus description. Transverse, strongly concave with regularly rounded lateral edges, maximum width on posterior edge (Figs. 1, 2). PL: 0.446-

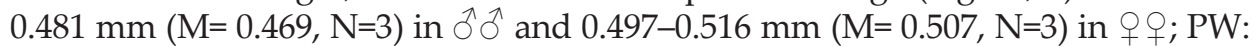

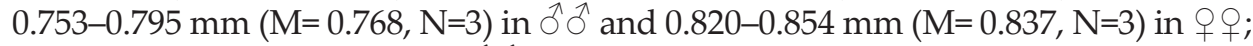

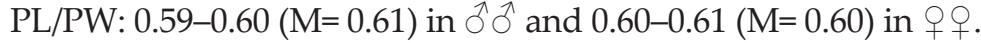


Thorax: As in genus description. Metendosternite (Fig. 11) as in other species of the genus.

Elytra: Elytra elongated-oval with maximum width on anterior part of elytra (Fig. 1). Strongly pubescent with uniform short and decumbent pubescence inserted in strong lateral rows - transversal striae on complete elytra surface, without sutural

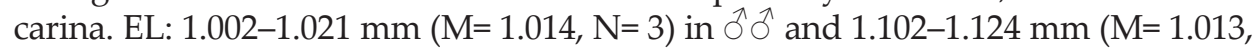
$\mathrm{N}=3)$ in 9 우 $\mathrm{EW}: 0.753-0.795 \mathrm{~mm}(\mathrm{M}=0.768, \mathrm{~N}=7)$ in $\lesssim \widehat{\jmath}$ and $0.840-0.841 \mathrm{~mm}(\mathrm{M}=$

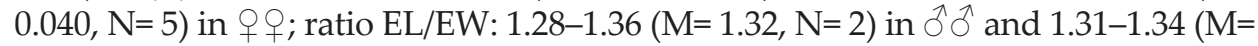
$1.32, \mathrm{~N}=2$ ) in 9 우.

Legs: Short and stout as in other species of the genus (Figs. 5-8). PtarL: 0.172$0.179(\mathrm{M}=0.175, \mathrm{~N}=3) \mathrm{mm}$ in $\widehat{\partial} \widehat{\sigma}$ and $0.176-0.192(\mathrm{M}=0.182, \mathrm{~N}=5) \mathrm{mm}$ in 우; PtarW: $0.020-0.025(\mathrm{M}=0.023, \mathrm{~N}=3) \mathrm{mm}$ in $\hat{\sigma} \widehat{\delta} \&$ \& 9 , not dilated at both sexes; PtibL: $0.240-0.250(\mathrm{M}=0.246, \mathrm{~N}=3) \mathrm{mm}$ in $\widehat{\partial} \hat{\sigma}^{\mathrm{N}}, 0.248-0.29(\mathrm{M}=0.254, \mathrm{~N}=3) \mathrm{mm}$ in 우; PtibW: 0.047-0.052 (M=0.050, $\mathrm{N}=3) \mathrm{mm}$ in $\widehat{\partial} \hat{\jmath}, 0.047-0.055(\mathrm{M}=0.052, \mathrm{~N}=3)$ $\mathrm{mm}$ in 9 ㅇ․

Male genitalia: Aedeagus elongate, extremely small, AedL: 0.322-0.326 (M= 0.325, N=3) mm long. In dorsal view (Fig. 69) median lobe straight and slender, AedMaxW: at the apical third 0.058-0.061 (M=0.060, N=3) mm wide; AedMinW: at the basal third $0.038-0.041(\mathrm{M}=0.040, \mathrm{~N}=3) \mathrm{mm}$ wide. Apex of median lobe moderately rounded, not pointed (Fig. 69). Inner sac without visible sclerotized structures. AedL/AedMaxW: 5.3-5.6. Basal lamina parallel with median lobe, relatively short compared to other species of the genus but longer than in $B$. tristiculus and B. mljetensis sp. n. (Figs. 69, 70). BlamL: 0.085-0.091 (M=0.087, $\mathrm{N}=$ 3) mm long; BlamW: 0.058-0.060 (M=0.059, N=3) mm wide. AedL/BlamL: 3.53.8; BlamL/BlamW: 1.4-1.5. Aedeagus in lateral view (Fig. 70) almost straight. Parameres straight, parallel with median lobe, shorter than median lobe, with one apical and two subapical long setae, similar in size and length, protruding over median lobe apex (Fig. 69, 70). Male genital segment as in genus description.

Female genitalia: Female ventrite VIII (Fig. 14) and spermatheca as in genus description. Urite IX characteristic for the subgenus Bathyscidus s. str., stylomeres relatively short, wide with straight outer and convex inner edge (as in Fig. 63).

According to evident morphological differences with B. tristiculus, especially aedeagus shape, we elevate the originally described subspecies $B$. tristiculus fallaciosus to species level $=B$. fallaciosus .

Differential diagnosis. Bathyscidius fallaciosus differs from other Bathyscidius species by the shape of the aedeagus median lobe apex, which is not pointed as in B. rambouseki and B. tomoricensis (Figs. 73, 75) but has a widely oval to semitriangular apex. $B$. orjensis has anextremely and for the genus unusually wide median lobe (Figs. 77, 78). B. tristiculus and B. mljetensis have a relatively longer aedeagus with its significantly narrow (subparallel) median lobes on the apical third (Figs. 65, 67). B. fallaciosus has a shorter and. on the apical third, a widened aedeagus median lobe similar to that of $B$. komajiensis. This two species can be easily distinguished by significant differences in antenna length compared to body size. $B$. fallaciosus has a significantly shorter antenna (AL): 0.576-0.589 mm in $\widehat{\partial} \widehat{\partial}$ and $0.585-0.602 \mathrm{~mm}$ in $Q$ + 0 than $B$. komajiensis, which has the longest antenna (AL): $0.700-0.749 \mathrm{~mm}$ in $\widehat{\partial} \hat{\sigma}$ and $0.712-0.749 \mathrm{~mm}$ in $q$ क ; among all known species of genus. In $B$. fallaciosus $8^{\text {th }}-10^{\text {th }}$ antennomeres are shorter than wide, unlike $B$. 
komajiensis where the $8^{\text {th }}-10^{\text {th }}$ antennomeres are longer than wide. Otherwise, $B$. fallaciosus is of similar body size to B. komajiensis.

Distribution. The species is known only from its type locality Vilina špilja at Ombla Spring and reported from Jama kod Bosanke (Schacht bei Bosanka), Bosanka near Dubrovnik collected by V. 1925 Winkler on May 1925 (Pretner, 1973).

Ecology. Specimens of $B$. fallaciosus were collected in Vilina špilja at Ombla Spring, which is a well-known extensive cave system measuring a total of 3063 $\mathrm{m}$ of passages (JALžıć et al. 2013). The specimens were mostly collected in the upper part of the cave system, approximately $100 \mathrm{~m}$ from the entrance, on the bottom of a tunnel, in proximity to bat guano deposits. On the site $100 \%$ humidity, temperature $16.2^{\circ} \mathrm{C}$ and $\mathrm{CO}_{2}$ concentration $281 \mathrm{ppm}$ were measured on 29.03.2008.

Bathyscidius komajiensis Polak \& Jalžić sp. $\mathbf{n}$.

Figs. 31-44, 71-72, 85-86.

Type locality. Bezdan (Synonyms: Jama Vignji, Bezdanka, Jama Bezdan Pit), situated near the village of Komaji, Konavle, near Dubrovnik in Southern Dalmatia (Croatia) (Figs. 44, 91).

Material Examined: specimens as declared in the type series.

Description.

Size: Total body length (BL): $1.33-1.55 \mathrm{~mm}(\mathrm{M}=1.470, \mathrm{~N}=6)$ in ${ }^{\lambda} \mathrm{o}^{\lambda}$ and $1.43-1.56$ $\mathrm{mm}(\mathrm{M}=1.484, \mathrm{~N}=8)$ in + 우. Colour: Yellowish to reddish brown, antenna and legs slightly paler. Antenna: (Figs. 36, 37, 85, 86) Antenna total length (AL): 0.700-0.749 $\mathrm{mm}(\mathrm{M}=0.719, \mathrm{~N}=4)$ in $0.7 \mathrm{~d}$ and $0.712-0.765 \mathrm{~mm}(\mathrm{M}=0.733, \mathrm{~N}=4)$ in 우; AL/PL: $1.39-1.50(\mathrm{M}=1.43)$ 우우 in and 1.42-1.43 $(\mathrm{M}=1.42)$ in 우우.

AmL ôे ô: 0.077-0.081; 0.101-0.113; 0.064-0.066; 0.045-0.050; 0.047-0.052; 0.038$0.045 ; 0.061-0.069 ; 0.042-0.43 ; 0.054-0.060 ; 0.050-0.058 ; 0.108-0.1118(\mathrm{~N}=4)$.

AmL 우: 0.081-0.090; 0.107-0.119; 0.059-0.076; 0.043-0.052; 0.046-0.053; 0.042$0.047 ; 0.062-0.069 ; 0.040-0.044 ; 0.051-0.057 ; 0.051-0.055 ; 0.109-0.112(\mathrm{~N}=4)$.

AL/AmL (in \%) ổ $10.99 ; 14.89 ; 9.04 ; 6.64 ; 6.78 ; 5.95 ; 8.94 ; 5.88 ; 7.93 ; 7.48 ; 15.48$.

AL/AmL (in \%) 우 우 $11.87 ; 15.42 ; 8.90 ; 6.45 ; 6.92 ; 6.07 ; 8.97 ; 5.73 ; 7.30 ; 7.26 ; 15.11$.

$\mathrm{AmL} / \mathrm{W}$ oे 0 : $1.98 ; 3.32 ; 3.02 ; 2.17 ; 2.65 ; 1.63 ; 1.68 ; 1.16 ; 1.23 ; 1.08 ; 1.92$.

$\mathrm{AmL} / \mathrm{W}$ 우우: $2.16 ; 3.70 ; 3.18 ; 2.22 ; 2.16 ; 1.76 ; 1.92 ; 1.29 ; 1.23 ; 1.10 ; 2.02$.

Pronotum: Transverse, strongly concave with regularly rounded lateral edges, maximum width on posterior edge (Figs. 31, 32). Dorsal face strongly pubescent with uniform short and decumbent pubescence, without order. PL: 0.466-0.539 $\mathrm{mm}(\mathrm{M}=0.503, \mathrm{~N}=4)$ in $\hat{\sigma}^{\lambda}$ and $0.494-0.537 \mathrm{~mm}(\mathrm{M}=0.516, \mathrm{~N}=4)$ in 우우 $\mathrm{PW}$ : $0.735-0.788 \mathrm{~mm}(\mathrm{M}=0.762, \mathrm{~N}=2)$ in ${ }^{\lambda} \mathrm{o}^{-}$and $0.822-0.831 \mathrm{~mm}(\mathrm{M}=0.827, \mathrm{~N}=2)$ in 우; PL/PW 0.60-0.61 (M=0.61) in ô ô and 0.63-0.68 (M=0.66) 우우.

Thorax: Mesosternal carina well developed, elevated, moderately thick, on ventral edge flattened not lanceolate, extended over the metasternum, almost reaching the metasternal intercoxal apophysis (Fig. 35). Metendosternite as in other species of the genus (Fig. 11). Metatergal apparatus with lateral processes strongly reduced and with moderately long apophysis as in other species of the genus (Figs. 9, 10). 

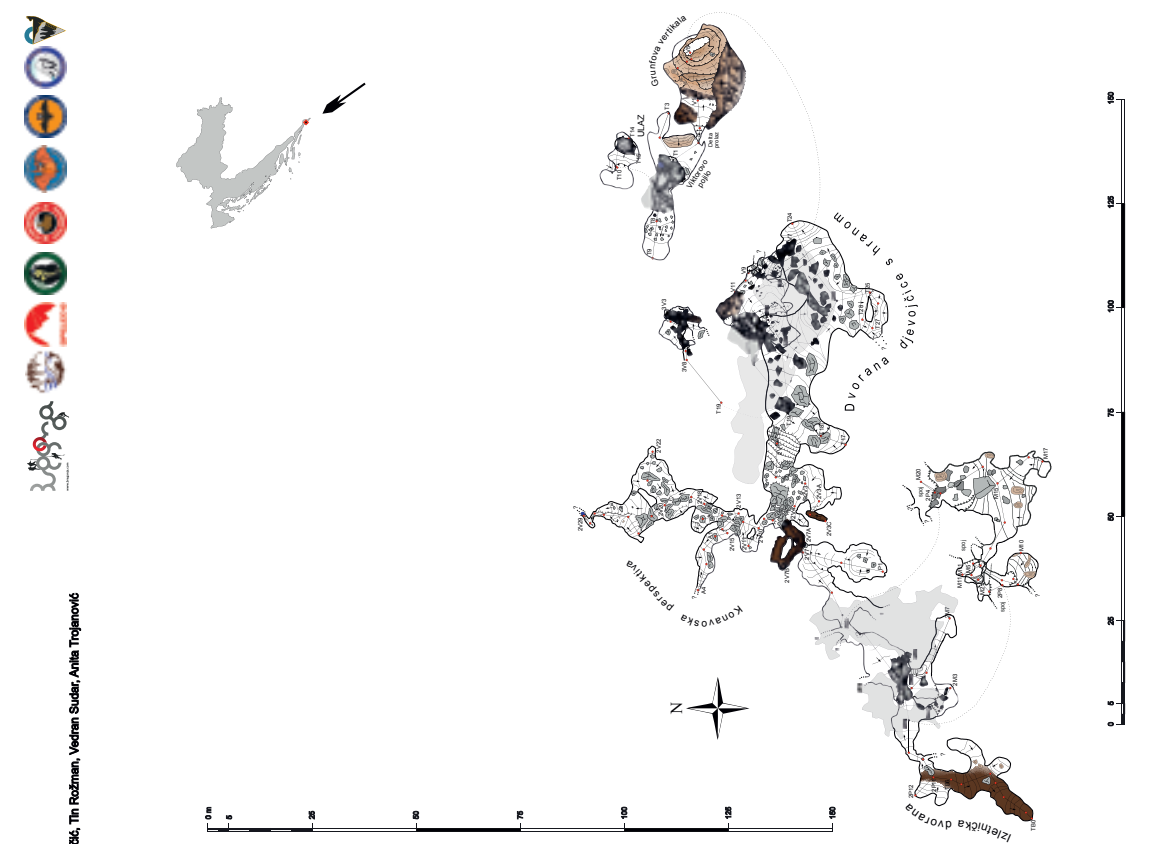

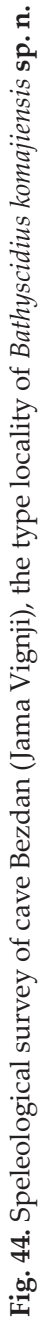


Elytra: Elytra elongated-oval with maximum width on anterior part of elytra (Figs. 33, 34). Strongly pubescent with uniform short and decumbent pubescence inserted in strong lateral rows - transversal striae on complete elytra surface,

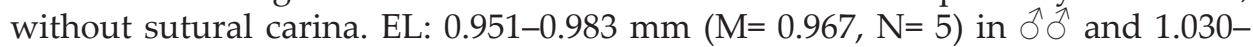

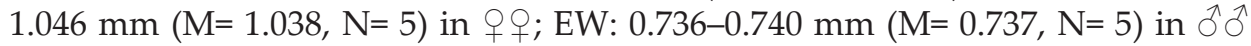
and $0.819-0.841 \mathrm{~mm}(\mathrm{M}=0.830, \mathrm{~N}=5)$ in 우우 ratio EL/EW: $1.29-1.34(\mathrm{M}=1.31)$ in

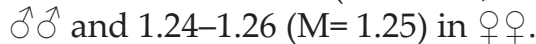

Legs: Short and stout as in other species of the genus (Figs. 5-8). Male and female protarsi 4-segmented. PtarL: 0.180-0.185 (M=0.183, N=5) $\mathrm{mm}$ in $\hat{\sigma}^{\hat{\partial}} \hat{\sigma}^{\lambda}$ and 0.174-0.190 ( $\mathrm{M}=0.183, \mathrm{~N}=5) \mathrm{mm}$ in 우; PtarW: 0.019-0.023 ( $\mathrm{M}=0.021, \mathrm{~N}=5) \mathrm{mm}$ in $\widehat{\partial} \widehat{\partial} \&$ 우, not dilated at both sexes; PtibL: $0.238-0.246(\mathrm{M}=0.242, \mathrm{~N}=5) \mathrm{mm}$ in

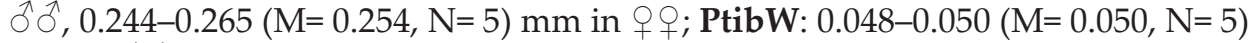

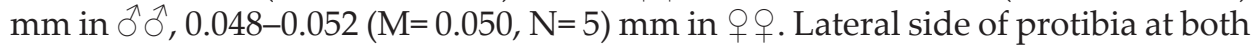
sexes armed with distinct comb of flat spines and two apical polident spur as in other species of the genus (Figs. 5-6).

Male genitalia: Aedeagus elongated, extremely small, AedL: 0.288-0.304 (M= 0.297, $\mathrm{N}=4$ ) $\mathrm{mm}$ long. In dorsal view (Figs. 38, 71) median lobe straight and slender, AedMaxW; at the apical third 0.055-0.058 ( $\mathrm{M}=0.057, \mathrm{~N}=4) \mathrm{mm}$ wide; AedMinW; at the basal third 0.031-0.035 (M=0.033, N=4) mm wide. Apex of median lobe moderately rounded, not pointed (Fig. 38, 71). Inner sac without visible sclerotized structures. AedL/AedMaxW: 7.4-8.3. Basal lamina parallel with median lobe, relatively short compared to other species of the genus (Figs. 38, 71). BlamL: 0.077-0.083 ( $\mathrm{M}=0.080, \mathrm{~N}=4) \mathrm{mm}$ long; BlamW: 0.065-0.074 ( $\mathrm{M}=$ 0.069, N=5) mm wide. AedL/BlamL: 3.5-3.9; BlamL/BlamW: 1.0-1.3. Aedeagus in lateral view (Fig. 39, 72) almost straight. Parameres straight, parallel with median lobe, shorter than median lobe, with one apical seta and two subapical long setae, similar in size and length, protruding over median lobe apex (Figs. 38, 39, 70, 71). Male genital segment in dorsal view annular, in lateral view (Fig. 40) with significant hood on the side, similar to other species of the genus.

Female genitalia: Female ventrite VIII (Fig. 41) strongly haired on proximal part with anterior stout or slim apophysis of medium length. Urite IX characteristic for the subgenus Bathyscidius s. str., stylomeres relatively short, wide with straight outer and convex inner edge (Fig. 42). Sub-gonocoxite with one stylus, gonocoxite with one basal, one lateral and two subapical styles, gonostylus with one longest stylus. Spermatheca (Fig. 43) sack-like or sausage-like, curved, uniformly and weakly sclerotized, rounded distally. Hyaline gland attached to the spermathecal duct at the proximal part of spermatheca.

Differential diagnosis. Bathyscidius komajiensis differs from other Bathyscidius species by the shape of the aedeagus median lobe apex, which is not pointed as in $B$. rambouseki and B. tomoricensis (Figs. 72,75 ) but has a widely oval to semitriangular apex. B. orjensis has an extremely and for the genus unusually wide median lobe (Fig. 77). B. tristiculus and B. mljetensis have relatively longer aedeagus with significantly narrow (subparallel) median lobes on apical third (Figs. 65, 67). B. komajiensis has a shorter and on the apical third widened aedeagus median lobe like that of $B$. fallaciosus. These two species can be easily distinguished by the significant differences in antenna length compared to body size. B. komajiensis

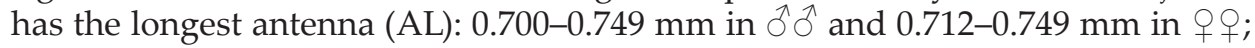


among all known species of genus. B. fallaciosus has significantly shorter antenna (AL): 0.576-0.589 $\mathrm{mm}$ in $\partial^{\lambda} \partial^{\lambda}$ and $0.585-0.602 \mathrm{~mm}$ in 90 .

In $B$. komajiensis $8^{\text {th }}-10^{\text {th }}$ antennomeres are longer than wide, unlike $B$. fallaciosus where the $8^{\text {th }}-10^{\text {th }}$ antennomeres are shorter than wide. Otherwise, B. komajiensis is of similar body size as B. fallaciosus.

Etymology. The species epithet is a toponym derived from the name of Komaji village near Cilipi (Croatia), where the type locality, the cave Bezdan, is situated.

Distribution. The new species is known only from its type locality, the cave Bezdan near Komaji.

Ecology. Specimens of B. komajiensis sp. n. were collected on the bottom of the first vertical pit, about $25 \mathrm{~m}$ deep, of the cave named Bezdan (Jama Vignji) (JANJANIN, 2019). In the cave some other troglobiontic fauna was found (Ćurčić et al., 2012b). The specimens were collected mostly under the rock debris. The soil, leaf litter and anthropogenic waste occur at the site. On 31.10.2016 air temperature of $13.1^{\circ} \mathrm{C}$ was measured in the cave.

Type series. Holotype $\hat{\sigma}$, glued to a white card, pinned dry, aedeagus dissected and preserved immersed in Solakryl BMX media on a transparent label pinned under the specimen, labeled: HOLOTYPE I Bathyscidius komajiensis sp. n. I Polak \& Jalžić det., [rectangular red label, printed]. Second label: CROATIA, Cavtat, Čilipi, Komaji, Vignje, Bezdan (Jama Vignji), 6.6.2014, Jalžić, B. leg. [rectangular white label, printed], - (CNHM).

Paratypes: PARATYPE | Bathyscidius komajiensis sp. n. | Polak \& Jalžić det. [rectangular yellow label, printed]. Second label: [rectangular white label, printed], specimen glued to white card, pinned dry, dissected genital parts and some body parts preserved immersed in Solakryl BMX media on a transparent label, pinned under the specimens : $4 \hat{\partial}$ and 9 $\bigcirc$, 6.6.2014, Jalžić, B. leg., same locality as the holotype - (CNHM); pinned dry, not dissected: $1 \overbrace{}^{\lambda}$ and $1 \stackrel{9}{\circ}$, 6.6.2014, Jalžić, B. leg., same locality as the holotype, pinned dry, not dissected:- (HBSD).

Specimens dissected (body parts, aedeagus, genital segments, protarsi, and antenna) preserved immersed in glycerine on glass microscope slides: $4 \hat{\partial} \partial \vec{~}$ and 4 우, 2.8.2011, Jalžić, B. leg., same locality as the holotype - (NMPO).

Bathyscidius orjensis Polak \& Jalžić sp. n.

Figs. 10, 12, 13, 45, 46, 47 -59, 73, 74, 87, 88.

Type locality. In the soil or superficial subterranean habitat near village Kruševice, Orjen Mountain, Southwestern Montenegro.

Material ExAmined: specimens as declared in type series.

DESCRIPTION.

Size: Total body length (BL): $1.20-1.39 \mathrm{~mm}(\mathrm{M}=1.324, \mathrm{~N}=10)$ in $\widehat{\jmath}$ and $1.32-$ $1.51 \mathrm{~mm}(\mathrm{M}=1.407, \mathrm{~N}=10)$ in $q$.. Colour: reddish brown, antenna and legs slightly paler. Antenna: (Figs. 52, 53, 91, 92) Antenna total length (AL): 0.495-0.541

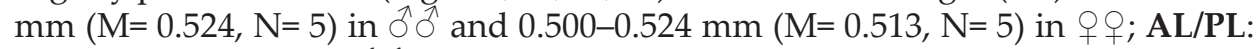
$1.13-1.38(\mathrm{M}=1.27)$ in $\widehat{\partial} \widehat{\partial}$ and $0.88-1.09(\mathrm{M}=0.98)$ in 9 우.

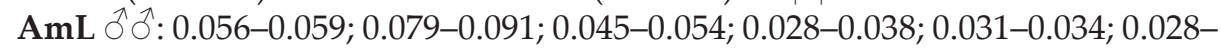
$0.030 ; 0.041-0.047 ; 0.023-0.028 ; 0.034-0.040 ; 0.038-0.042 ; 0.087-0.094(\mathrm{~N}=5)$. 
AmL $9+: 0.058-0.065 ; 0.080-0.088 ; 0.039-0.044 ; 0.029-0.032 ; 0.032-0.037 ; 0.028-$ $0.032 ; 0.042-0.045 ; 0.025-0.027 ; 0.034-0.037 ; 0.038-0.038 ; 0.084-0.091(\mathrm{~N}=5)$.

AL/AmL (in \%) ठึે: $11.03 ; 16.67 ; 9.41 ; 6.16 ; 6.16 ; 5.54 ; 8.31 ; 4.87 ; 7.16 ; 7.64 ; 17.05$.

AL/AmL (in \%) 우: $12.15 ; 16.18 ; 8.25 ; 5.91 ; 6.76 ; 5.85 ; 8.38 ; 5.13 ; 6.82 ; 7.41 ; 17.15$.

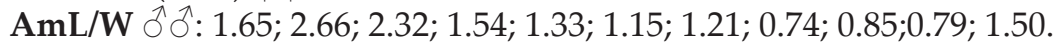

AmL/W $\circ \circ: 1.76 ; 2.65 ; 2.05 ; 1.44 ; 1.44 ; 1.13 ; 1.09 ; 0.69 ; 0.74 ; 0.74 ; 1.55$.
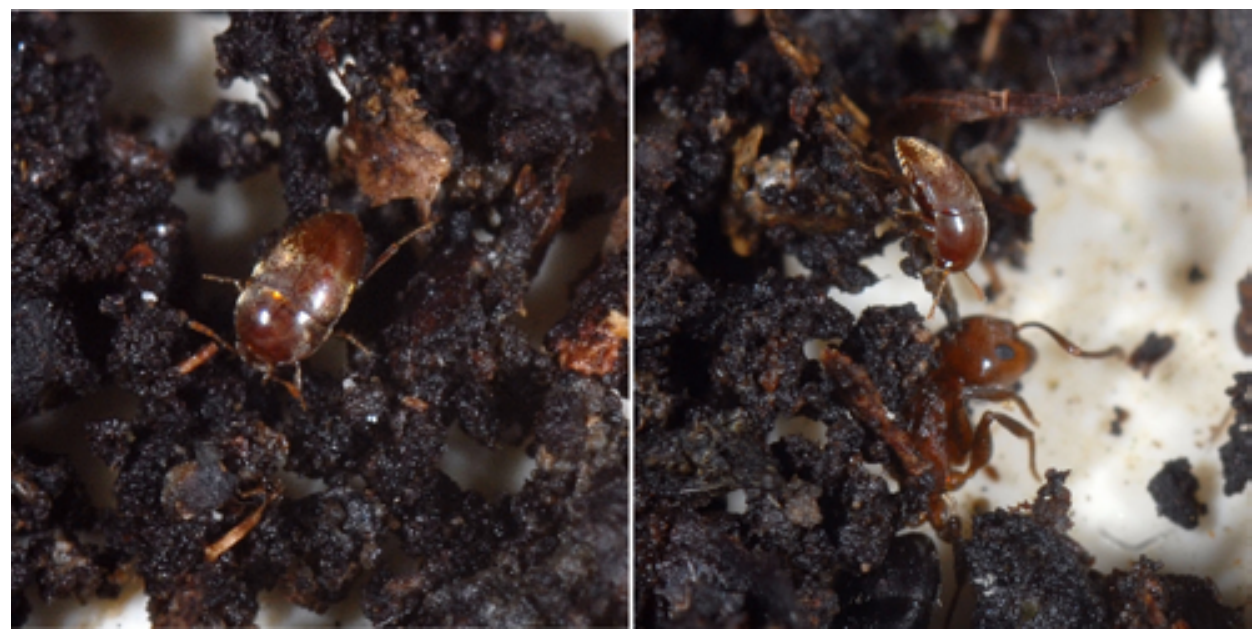

Figs. 45-46. Bathyscidius orjensis sp. $\mathbf{n}$. in its natural habitat wet soil on type locality near vilage Kruševice, Orjen (Montenegro). In Fig. 46. The Bathyscidius next to an unknown ant species.

Pronotum: Transverse, strongly concave with regularly rounded lateral edges, maximum width on posterior edge (Figs. 47, 48). Dorsal face strongly pubescent with uniform short and decumbent pubescence, without order. PL: 0.358-0.479

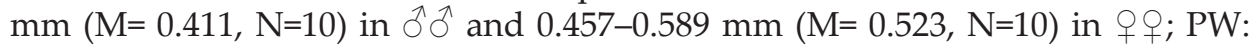

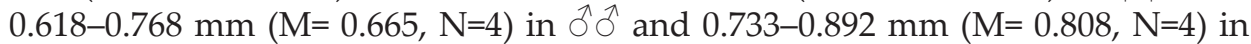

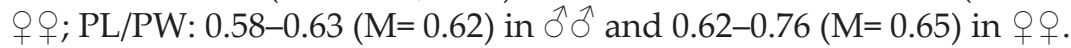

Thorax: Mesosternal carina well developed, elevated, moderately thick, on ventral edge flattened not lanceolate, extended over the metasternum, almost reaching the metasternal intercoxal apophysis (Fig. 51). Metendosternite as in other species of the genus (Fig. 11). Metatergal apparatus with lateral processes strongly reduced and with moderately long apophysis (Fig. 10) as in other species of the genus.

Elytra: Elytra elongated-oval with maximum width on anterior part of elytra (Figs. 49, 50). Strongly pubescent with uniform short and decumbent pubescence inserted in strong lateral rows - transversal striae on complete elytra surface, without sutural carina. EL: 0.835.-0.942 $\mathrm{mm}(\mathrm{M}=0.893, \mathrm{~N}=5)$ in $\widehat{\partial} \mathrm{\partial}$ and 0.935$0.988 \mathrm{~mm}(\mathrm{M}=0.972, \mathrm{~N}=5 \mathrm{in}$ 우; $\mathrm{EW}: 0.657-0.755 \mathrm{~mm}(\mathrm{M}=0.706, \mathrm{~N}=5)$ in $\widehat{\partial} \widehat{\jmath}$ and $0.790-0.815 \mathrm{~mm}(\mathrm{M}=0.800, \mathrm{~N}=5)$ in q 9 ; ratio EL/EW: $1.25-1.27(\mathrm{M}=1.26)$ in $\widehat{\partial} \widehat{\jmath}$ and 1.18-1.21 $(\mathrm{M}=1.21)$ in 9 우.

Legs: Short and stout as in other species of the genus (Figs. 5-8). Male and female protarsi 4-segmented. PtarL: 0.157-0.188 (M=0.167, $\mathrm{N}=5) \mathrm{mm}$ in $\hat{\partial} \hat{\mathrm{o}}$ and 0.169-0.170 (M=0.170, N= 5) mm in 우; PtarW: 0.019-0.022 (M=0.020, N= 5) mm 


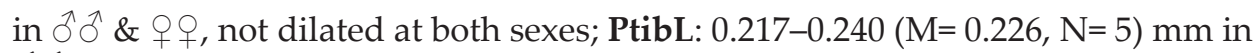

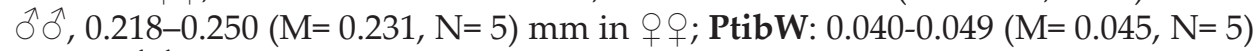
$\mathrm{mm}$ in $\widehat{\partial}, 0.039-0.050(\mathrm{M}=0.045, \mathrm{~N}=5) \mathrm{mm}$ in $q$. 9 . Lateral side of protibia in both sexes armed with distinct comb of flat spines and two apical polident spurs as in other species of the genus (Figs. 5-6).

Male genitalia: Aedeagus small, but bigger and wider than in other species of the genus. AedL: 0.372-0.406 ( $\mathrm{M}=0.389, \mathrm{~N}=4) \mathrm{mm}$ long. In dorsal view (Fig. 54, 77) median lobe straight and wide, AedMaxW: at mid-length 0.068-0.086 $(\mathrm{M}=0.080, \mathrm{~N}=4) \mathrm{mm}$ wide; AedMinW: at the basal third 0.050-0.073 (M=0.066, $\mathrm{N}=4$ ) mm wide. Apex of median lobe moderately rounded, not pointed and not flattened in lateral view (Fig 54, 55, 77, 78). Inner sac without visible sclerotized structures. AedL/AedMaxW: 4.8-5.5. Basal lamina parallel with median lobe, relatively long and wide compared to other species of the genus (Figs. 54, 77). BlamL: 0.117-0.152 ( $\mathrm{M}=0.139, \mathrm{~N}=4) \mathrm{mm}$ long, BlamW: 0.096-0.136 ( $\mathrm{M}=0.118$, $\mathrm{N}=5$ ) mm wide. AedL/BlamL: 3.6-4.9; BlamL/BlamW: 0.8-1.5. Aedeagus in lateral view (Fig. 55, 78) almost straight, cylindrical not dorso-ventrally flattened. Parameres straight, parallel with median lobe, shorter than median lobe, with one apical and two subapical long setae, similar in size and length, hardly protruding over the median lobe apex (Figs. 54, 55, 77, 78). Male genital segment in dorsal view annular, in lateral view with significant hood on the side (Fig. 56), like other species of the genus.

Female genitalia: Female ventrite VIII (Fig. 57) strongly haired on proximal part with anterior slim and long apophysis. Urite IX characteristic for the subgenus Bathyscidius s. str., stylomeres relatively short, wide with straight outer and convex inner edge (Fig. 58). Sub-gonocoxite with one stylus, gonocoxite with one basal, one lateral and two subapical styles, gonostylus with one longest stylus. Spermatheca (Fig. 59) sack-like or sausage-like, curved, uniformly and weakly sclerotized, rounded distally. Hyaline gland attached to the spermathecal duct at the proximal part of spermatheca.

Differential diagnosis. Bathyscidius orjensis differs from other Bathyscidius species by the shape of the aedeagus median lobe apex, which is not elongated and narrow as in other species but has an unusually wide, cylindrical and not dorso-ventrally flattened median lobe (Figs. 54, 55, 77, 78). B. orjensis has the shortest antennae among all known species of the genus. In $\hat{\delta} \hat{\delta}$ the antennae are just slightly longer than the pronotum (AL/PL: 1.13-1.38) and in $q$ q antennae can be even shorter (AL/PL: 0.88-1.09) than the pronotum.

Etymology. The species epithet is a toponym derived from the name of the Orjen Mountain.

Distribution. The new species is so far known only from its type locality, MSS habitat near Kruševice village (Fig. 60), on the southern slope of Mt Orjen, Montenegro, at the altitude of ca $750 \mathrm{~m}$ a.s.l.

Ecology. Specimens of B. orjensis sp. n. were collected during sifting of the humid black soil and pitfall trapping among the rock crevices on the base of a calcareous hill (Figs. 45, 46, 60). The finding place of B. orjensis is characteristic, with a cooler environment than the surroundings, since some cold airflow can be detected in the collecting microhabitat in summer. This presumably indicates existence of some 


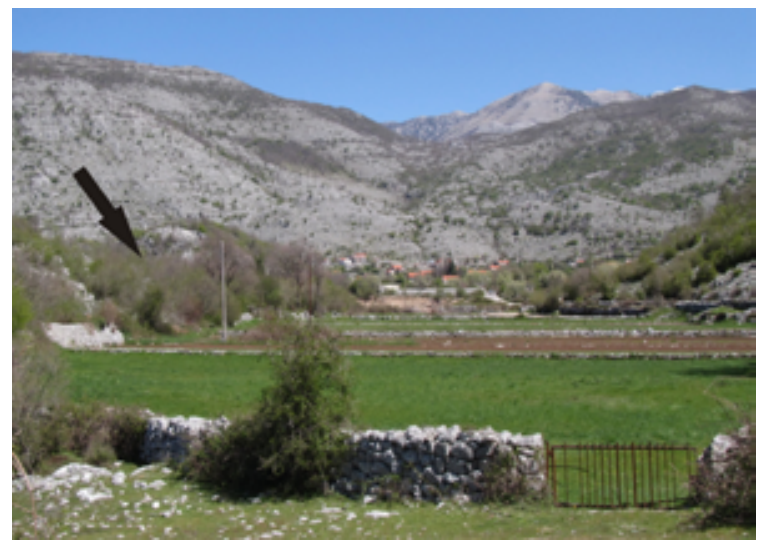

Fig. 60. The type locality of Bathyscidius orjensis sp. $\mathbf{n}$. on the base of an isolated hill near the village Kruševice, Orjen (Montenegro). Black arrow indicates exact finding place.

subterranean environment beneath the exact finding locality, so the original habitat of the new species is probably superficial underground compartment (Culver \& Pipan, 2009) or MSS - the Milieu Souterrain Superficiel (Juberthie et al., 1980), terrestrial shallow subterranean habitat rather than leaf litter.

Type series. Holotype $\widehat{\sigma}$, glued to a white card, pinned dry, aedeagus dissected and preserved immersed in Solakryl BMX media on a transparent label pinned below the specimen, labeled: HOLOTYPE | Bathyscidius orjensis sp. n. $ᄋ$ | Polak \& Jalžić det., [rectangular red label, printed]. Second label: MONTENEGRO, Orjen Mt., Kruševice, MSS. 1.8.2011, Polak, S. leg. [rectangular white label, printed], (NHMM).

Paratypes: PARATYPE | Bathyscidius orjensis sp. n. | Polak \& Jalžić det. [rectangular yellow label, printed]. Second label: [rectangular white label, printed], specimen glued to white card, pinned dry, not dissected: $10 \hat{\partial} \widehat{\delta}$ and 10 우우, 2.5.2010-1.8.2011, Polak, S. leg., same locality as the holotype - (NHMM); same locality and date $5 \hat{\jmath} \widehat{\jmath}$ and 5 우,- (CNHM); $5 \hat{\jmath}$ and 5 우, - (NHMT);

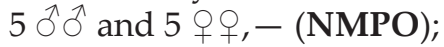

Specimens dissected (body parts, aedeagus, genital segments, protarsi, and antenna) preserved immersed in glycerine on glass microscope slides: 2 ते $\widehat{\sigma}$ and 1 , 10.4.2009 \& $4 \hat{\delta}$ and 2 oq, 1.8.2011, Polak, S. leg., same locality as the holotype - (NMPO).

\section{Ionobathyscidius subgenus nov.}

Type species: Bathyscidius rambouseki Knirsch, 1930

Differential diagnosis. Species from subgenus Ionobathyscidius differs from subgenus Bathyscidius s. str. species by the shape of the aedeagus median lobe apex, which is moderately pointed (Figs. 62, 73, 75), and not rounded or subtriangular as in species of the subgenus Bathyscidius s. str. Paramere apex is armed with three subapical erected setae inserted almost together (Figs. 62, 73-76), and not one apical and two lateral setae as in Bathyscidius s. str. (Fig. 24, 25, 38, 39, 54, 55, 61, 65-72, 77, 78). Females of the species from subgenus Ionobathyscidius have urite IX (genital segment-ovipositor) significantly different shape than species from Bathyscidius 
s. str. Stylomeres are longer and narrower, almost parallel sides of stylomeres have basally concave outer and straight or slightly convex inner edge. Contrary the Bathyscidius s. str. species have stylomeres relatively short, wide and bulky, appearing subtriangular in shape, with straight outer and significantly convex inner edges (Figs. 28, 42, 58, 63). On the lateral sides of the protibia in both sexes the distinct comb of flat spines is less strong and shorter, covering only the apical third of protibia, in contrast to the species of subgenus Bathycsidius s. str. where comb spines are stronger and cover approximately two apical thirds of the protibia.

Etymology. The subgenus name is a toponym derived from the name of the Ionian Sea and Bathyscidius. The distribution of species of subgenus Bathyscidius s. str. is influenced by the SE Adriatic Sea, unlike species belonging to subgenus Ionobathyscidius, which live more to the south in mountains regions, influenced by the Ionian Sea.

Distribution. Like the distribution of the species $B$ (I) rambouseki and $B(I)$ tomoricensis, in the SW part of Northern Macedonia and SE Albania.

\section{Bathyscidius (Ioniobathyscidius) rambouseki Knirsch, 1931}

Bathyscidius Rambouseki Knirsch, 1931, Čas. Cesk. Spol. Entomol., 28 (1-2): 3.

lct : Höhle oberhalb der Omblaquelle bei Ragusa (Dubrovnik), Dalmatien, Croatia.

Bathyscidius rambouzeki Kn.: Laneyrie, R., 1967, Ann. De Spéléologie. 22 (3), 611.

Bathyscidius rambouseki Knirsch, 1931: Pretner, 1968: Catalogus Faunae Jug. III. (6), 20.

Bathyscidius rambouseki Knirsch, 1931: Perreau, 2000: Mem. Sef, 4.: 193.

Bathyscidius rambouseki Knirsch, 1931: Perreau, 2004: Catalogue of Palaearctic Coleoptera. Vol 2:153.

Bathyscidius rambouseki Knirsch, 1931: Perreau, 2015: Catalogue of Palaearctic Coleoptera: 180-290.

Bathyscidius rambouseki Knirsch, 1931: Hlaváč, P., Perreau, M., Čeplík, D., 2017: Czhec Univ. of Life Csci, Pague, 100.

The species was described by Edmund Knirsch (KNIRsCH, 1931) on the basis of one male and 3 females, collected by F. Rambousek in Galičica Mountain in Northern Macedonia. The original description (translated from German) is follows: "The copulation organ very slender, $0.45 \mathrm{~mm}$ long, with almost parallel sides and in the apical parts with two lateral dorsally curved longitudinal lobes before the short, rounded and at the end suddenly narrowed tip. The basal plate (basal lamina) long and narrow, tapering backwards. Parameres straight, on the end with three setae pointed together. Bright, reddish yellow. Antenna short, slender, the $8^{\text {th }}$ antennomere rounded, $9^{\text {th }}$ and $10^{\text {th }}$ transverse. Long $1.4 \mathrm{~mm}$. On the Galičica planina above the village of Trpezica at Ochrid Lake in Macedonia at an altitude of some $1500 \mathrm{~m}$, sifted from the hollow of a horse chestnut at the beginning of October 1926. One male and 3 females in my collection."

Because of the shorter antennas and the very slender copulation organ, and considering the long basal plate in B. tomoricensis easily distinguished from this, as well as from the other Bathsycidius species according to wholly different copulation organ, and the other constitution of the $8^{\text {th }}-10^{\text {th }}$ antennomeres.

Material Examined: Ohrid (Northern Macedonia), Galičica Mountain, southern slope above Trpezica village in leaf litter at ca $800 \mathrm{~m}$ a.s.l., 1 त \& 2 우, 01.05.2009, S. Polak leg., (NMPO); $4 \partial^{\lambda} \partial^{\top} \& 6$ 우, 23.07.2009, S. Polak leg., (NMPO). 
REDESCRIPTION.

Size: Total body length (BL): $1.35-1.37 \mathrm{~mm}(\mathrm{~N}=3)$ in $\widehat{\jmath} \hat{\partial}$ and $1.46-1.53 \mathrm{~mm}$ $(\mathrm{N}=3)$ in 9 .. Colour: Reddish brown, antenna and legs slightly paler. Antenna:

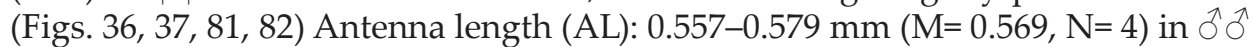

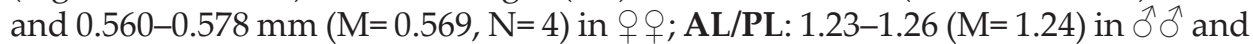
1.07-1.18 (M=1.11) in 우.

AmL: $\widehat{\widehat{\partial}}$ : $0.060-0.066 ; 0.081-0.090 ; 0.043-0.048 ; 0.036-0.038 ; 0.035-0.041$; $0.030-0.035 ; 0.048-0.053 ; 0.027-0.32 ; 0.039-0.043 ; 0.043-0.045 ; 0.102-0.103(\mathrm{~N}=4)$.

AmL: $q$ 우: 0.062-0.065; 0.087-0.089; 0.041-0.049; 0.036-0.037; 0.039-0.046; $0.033-0.035 ; 0.051-0.052 ; 0.029-0.043 ; 0.041-0.041 ; 0.042-0.045 ; 0.094-0.096(\mathrm{~N}=4)$.

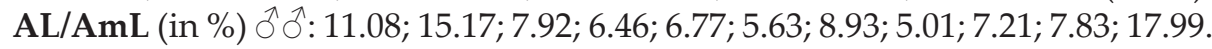

AL/AmL (in \%) 90 : $11.16 ; 15.51 ; 7.86 ; 6.41 ; 7.29 ; 5.93 ; 9.09 ; 5.14 ; 7.21 ; 7.64 ; 16.47$.

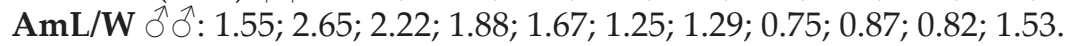

AmL/W $ᄋ$ $: 1.73 ; 2.82 ; 2.21 ; 1.87 ; 1.84 ; 1.31 ; 1.40 ; 0.87 ; 0.96 ; 0.92 ; 1.96$.

Pronotum: Transverse, strongly concave with regularly rounded lateral edges, maximum width on posterior edge. PL: 0.452-0.459 $\mathrm{mm}(\mathrm{M}=0.456, \mathrm{~N}=3)$ in $\hat{\partial} \widehat{\partial}$ and $0.471-0.540 \mathrm{~mm}(\mathrm{M}=0.510, \mathrm{~N}=3)$ in + o $+\mathrm{PW}: 0.726-0.758 \mathrm{~mm}(\mathrm{M}=0.742, \mathrm{~N}=3)$ in $\widehat{\partial}$ and $0.749-0.770 \mathrm{~mm}(\mathrm{M}=0.759, \mathrm{~N}=3)$ in 9 우 $\mathrm{PL} / \mathrm{PW}: 0.60-0.62(\mathrm{M}=0.61)$ in ठิ $\hat{\sigma}$ and $0.63-0.70(\mathrm{M}=0.67)$ in $ㅇ ㅜ$.

Thorax: Mesosternal carina well developed, elevated, moderately thick, extended over the metasternum, almost reaching the metasternal intercoxal apophysis. Metendosternite and metatergal apparatus as in other species of the genus.

Elytra: Elytra elongated-oval with maximum width on anterior part of elytra. Strongly pubescent with uniform short and decumbent pubescence inserted in strong lateral rows - transversal striae on complete elytra surface, without sutural

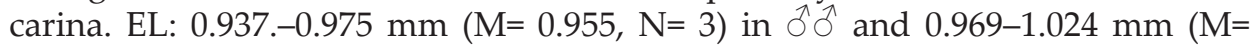
0.997, $\mathrm{N}=3)$ in 우; $\mathrm{EW}: 0.706-0.750 \mathrm{~mm}(\mathrm{M}=0.730, \mathrm{~N}=3)$ in $\widehat{\jmath} \widehat{\jmath}$ and $0.820-0.860$

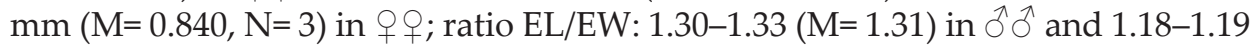
$(\mathrm{M}=1.19)$ in $q$ ㅇ․

Legs: Short and stout as in other species of the genus (Figs. 5-8). Male and female protarsi 4-segmented. PtarL: 0.160-0.173 (M=0.167, N=5) $\mathrm{mm}$ in $\widehat{\partial} \widehat{\partial}$ and 0.175-0.185 (M=0.181, N= 5) mm in o o ; PtarW: 0.019-0.020 (M=0.020, N= 5) mm

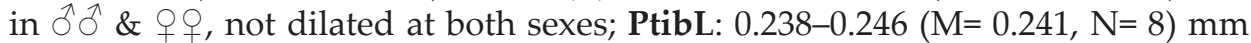
in 9 ㅇ, $0.243-0.248(\mathrm{M}=0.245, \mathrm{~N}=6) \mathrm{mm}$ in ôें PtibW: 0.043-0.051 (M=0.047, N=

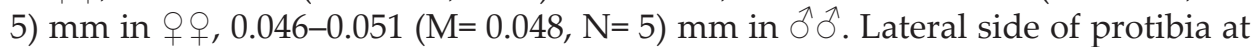
both sexes armed with distinct comb of flat spines (less strong and shorter than in species of subgenus Bathyscidius s. str.) and two apical polident spurs as in other species of the genus (Figs. 5-6).

Male genitalia: Aedeagus elongated, narrow. AedL: 0.365-0.392 (M=0.380, N= 3) mm long. In dorsal view (Fig. 75) median lobe straight and slender, AedMaxW: median lobe widest at the central third 0.054-0.056 (M=0.055, N=4) mm wide; AedMinW: at the basal third 0.043-0.047 (M=0.045, $\mathrm{N}=4) \mathrm{mm}$ wide. Apex of median lobe in the apical part with two lateral dorsally curved longitudinal lobes. Apex rounded at the end suddenly narrowed with rounded, not pointed tip. (Figs. 62, 75). Inner sac without visible sclerotized structures. AedL/AedMaxW: 
6.8-7.1. Basal lamina parallel with median lobe, relatively long compared to other species of the genus (Figs. 75, 76). BlamL: 0.099-0.123 ( $\mathrm{M}=0.112, \mathrm{~N}=4) \mathrm{mm}$ long; BlamW: 0.062-0.090 ( $\mathrm{M}=0.082, \mathrm{~N}=5) \mathrm{mm}$ wide. AedL/BlamL: 3.2-3.7; BlamL/ BlamW: 1.1-1.4. Aedeagus in lateral view (Fig. 76) almost straight, parallel, only slightly curved at the medial part. Apex pointed. Parameres straight, parallel with median lobe, shorter than median lobe, with three subapical long setae, similar in size and length, protruding almost to the median lobe apex (Figs. 62, 75, 76). Male genital segment in dorsal view ring-like, annular, in lateral view with significant hood on the side, like other species of the genus.

Female genitalia: Female ventrite VIII strongly haired on proximal part with anterior stout or slim apophysis of medium length. Urite IX (Fig. 64) is characteristic for the subgenus Ionobathyscidius, stylomeres basally concave or straight outer and moderately convex inner edge (Fig. 64). Sub-gonocoxite with one stylus, gonocoxite with one basal, one lateral and two subapical styles, gonostylus with one longest stylus. Spermatheca sack-like or sausage-like, curved, uniformly and weakly sclerotized, rounded distally similar to the other species of the genus.

Bathyscidius (Ioniobathyscidius) tomoricensis Müller, 1922

Bathyscidius tristiculus sbsp. tomoricensis Müller,1922: Boll. Soc. entomol. Ital., 54: 89.

lct : Monte Tomorica et Toik regionis "Tomor"

Bathyscidius tomoricensis J. Müller, 1922: JeAnneL, 1924, Arch. Zool. expe. Gén., 63 (1): 269.

Bathyscidius tomoricensis Müll.: LANEYrie, R., 1967, Ann. De Spéléologie. 22 (3), 611.

Bathyscidius tomoricensis J. Müller, 1922: Perreau, 2000: Mem. Sef, 4.: 193.

Bathyscidius tomoricensis Müller, 1922: Perreau, 2004: Catalogue of Palaearctic Coleoptera. Vol 2:153.

Bathyscidius tomoricensis Müller, 1922: Perreau, 2015: Catalogue of Palaearctic Coleoptera: 180-290.

Bathyscidius tomoricensis J.(G.) Müller, 1922: Hlaváč, P., Perreau, M., Čeplík, D., 2017: Czhec Univ. of Life Csci, Pague, 100.

The species was described by Joseph (Giuseppe) Müller (MüLler, 1922) as a subspecies of $B$. tristiculus based on specimens collected by C. Lona and G. Ravasini and from Trieste on July 1922 in Albania.

The original diagnosis is follows (in Latin): "A forma typica antennis brevioribus peneque, a subspecie fallaciosa m. tantummodo pene magnis elongato, exiliori di stincta (with 2 aedeagus drawings). Habit in monte Tomorica et Toik regionis "Tomor" dictae, sub lapidus. "In the original description Müller added (translated from Italian): "Despite careful microscopic examination, I find no other difference between this Bathyscidius from Albania and other races from southern Dalmatia, which has slightly slender and narrower penis shape. Unfortunately, due to an inaccuracy in my paper published in Sitzungsber, Akad, Wien, 1917, Taf. I, fig. 11, I reproduce here the penis images of all three known forms of B. tristiculus based on new original drawings".

Type locality. Tomorica and Toik Mountain on Tomor Mountain range in southern Albania near Berat (Southern Albania) (Fig. 95).

Material Examined: Berat (Southern Albania), Toik, Tomorica, Tomor, under the stones on cca $1500 \mathrm{~m}$ a.s.l., 3 \& \& 4 우, 1922, Ravasini leg., (NHMT); Tomor:

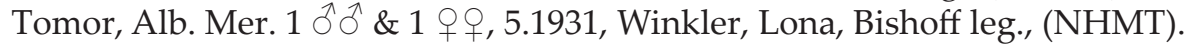


REDESCRIPTION.

Size: Total body length (BL): $1.35-1.37 \mathrm{~mm}(\mathrm{~N}=3)$ in $\widehat{\jmath} \hat{\partial}$ and $1.46-1.53 \mathrm{~mm}$ $(\mathrm{N}=3)$ in $\circ \circ$. Colour: Reddish brown, antenna and legs slightly paler. Antenna:

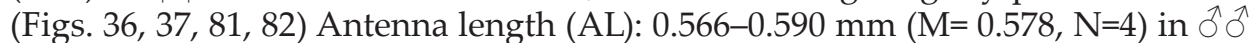

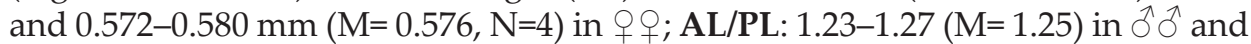
$1.20-1.26(\mathrm{M}=1.23)$ in 9 우.

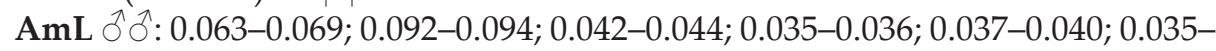
$0.035 ; 0.053-0.054 ; 0.022-0.26 ; 0.039-0.041 ; 0.042-0.044 ; 0.107-0.108(\mathrm{~N}=4)$.

AmL 우: $0.063-0.068 ; 0.092-0.097 ; 0.045-0.047 ; 0.034-0.034 ; 0.040-0.040 ; 0.033-$ $0.035 ; 0.053-0.057 ; 0.029-0.030 ; 0.038-0.041 ; 0.041-0.043 ; 0.095-0.097(\mathrm{~N}=4)$.

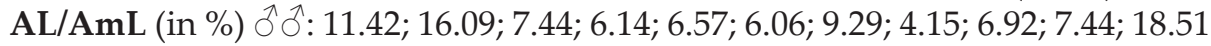
$(\mathrm{N}=4)$.

AL/AmL (in \%) $q$ q : $11.37 ; 16.41 ; 7.99 ; 5.90 ; 6.94 ; 5.90 ; 9.55 ; 5.12 ; 6.86 ; 7.29 ; 16.67$ $(\mathrm{N}=4)$.

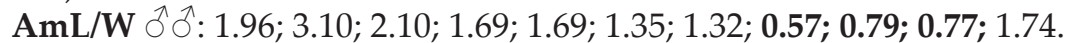

$\mathrm{AmL} / \mathrm{W} \bigcirc \circ: 1.62 ; 2.95 ; 2.19 ; 1.66 ; 1.78 ; 1.28 ; 1.31 ; 0.68 ; 0.75 ; 0.73 ; 1.51$.

Pronotum: Transverse, strongly concave with regularly rounded lateral edges, maximum width on posterior edge. PL: $0.445-0.480 \mathrm{~mm}(\mathrm{M}=0.462, \mathrm{~N}=2)$ in $\hat{\partial} \widehat{\partial}$ and $0.452-0.485 \mathrm{~mm}(\mathrm{M}=0.468, \mathrm{~N}=2)$ in + o $; \mathrm{PW}: 0.760-0.782 \mathrm{~mm}(\mathrm{M}=0.771, \mathrm{~N}=2)$ in $\widehat{\partial}$ and $0.770-0.830 \mathrm{~mm}(\mathrm{M}=0.800, \mathrm{~N}=2)$ in 9 우 $\mathrm{PL} / \mathrm{PW}: 0.58-0.61(\mathrm{M}=0.59)$ in ठิ $\hat{\sigma}$ and $0.58-0.59(\mathrm{M}=0.59)$ in $\circ$ 우.

Thorax: Mesosternal carina well developed, elevated, moderately thick, on ventral edge flattened not lanceolate, extended over the metasternum, almost reaching the metasternal intercoxal apophysis. Metendosternite (Crowson's organ) and metatergal apparatus as in other species of the genus.

Elytra: Elytra elongated-oval with maximum width on anterior part of elytra. Strongly pubescent with uniform short and decumbent pubescence inserted in strong lateral rows - transversal striae on complete elytra surface, without sutural

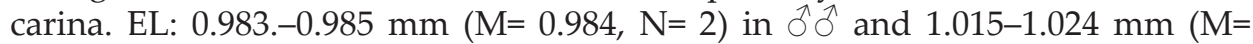
1.019, $\mathrm{N}=2$ in $ᄋ$ 우 $\mathrm{EW}: 0.770-0.780 \mathrm{~mm}(\mathrm{M}=0.775, \mathrm{~N}=2)$ in $\widehat{\partial} \widehat{\jmath}$ and $0.822-0.830$

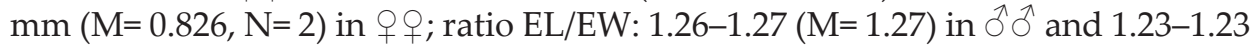
$(\mathrm{M}=1.23)$ in 우.

Legs: Short and stout as in other species of the genus. Male and female protarsi 4-segmented. PtarL: 0.188-0.189 (M=0.189, $\mathrm{N}=2) \mathrm{mm}$ in $\widehat{\partial} \widehat{\partial}$ and 0.188-0.199 (M=

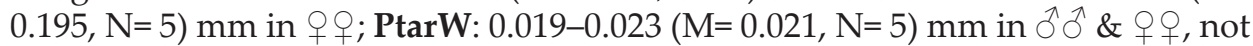

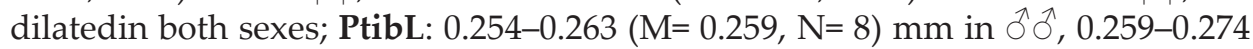
$(\mathrm{M}=0.265, \mathrm{~N}=6) \mathrm{mm}$ in 9 + ; PtibW: 0.050-0.051 $(\mathrm{M}=0.051, \mathrm{~N}=5) \mathrm{mm}$ in $\widehat{\partial}$, 0.046-0.051 $(\mathrm{M}=0.074, \mathrm{~N}=5) \mathrm{mm}$ in $\circ$ +. Lateral side of protibia at both sexes armed with distinct comb of flat spines (less strong than in species of subgenus Bathyscidius s. str.) and two apical polident spurs similar to those in other species of the genus (Figs. 5-6).

Male genitalia: Aedeagus extremely elongated, straight, slim and long, AedL: 0.393-0.397 (M=0.395, N=4) mm long. In dorsal view (Fig. 73) median lobe straight parallel and slender, AedMaxW: in the medial third 0.040-0.047 (M=0.044, N=4) mm wide; AedMinW: at the basal third 0.034-0.037 (M=0.036, $\mathrm{N}=4) \mathrm{mm}$ wide. Apex of median lobe rounded at the end slowly narrowed (subtriangular) with 
rounded, not pointed tip. (Fig. 73). Inner sac without visible sclerotized structures. AedL/AedMaxW: 9.1-9.8. Basal lamina parallel with median lobe, extremely long and narrow compared to other species of the genus (Figs. 73, 74). BlamL: 0.145-0.149 ( $\mathrm{M}=0.147, \mathrm{~N}=4) \mathrm{mm}$ long. BlamW: 0.047-0.048 ( $\mathrm{M}=0.048, \mathrm{~N}=5)$ mm wide. AedL/BlamL: 2.7; BlamL/BlamW: 3.0-3.1. Aedeagus in lateral view (Fig. 74) almost straight. Parameres straight, parallel with median lobe, shorter than median lobe, with three subapical long setae, similar in size and length, protruding almost to median lobe apex (Figs. 73, 74). Male genital segment in dorsal view annular, in lateral view with significant hood on the side, similar to other species of the genus.

Female genitalia: Female ventrite VIII strongly haired on proximal part with anterior stout or slim apophysis of medium length. The urite IX characteristic is similar to that of B. rambouseki (Fig. 64) and characteristic or the subgenus Ionobathyscidius. Stylomeres have basally concave outer and moderately convex inner edges Sub-gonocoxite with one stylus, gonocoxite with one basal, one lateral and two subapical styles, gonostylus with one longest stylus. Spermatheca sacklike or sausage-like, curved, uniformly and weakly sclerotized, rounded distally similar to the other species of the genus.

Bathyscidius remyi Jeannel 1934 = Laneyriella andijevicenis (Jeannel, 1924) syn. nov.

Bathyscidius Remyi Jeannel, 1934, Rev. fr. Entomol., 1: 100.

lct : Sandjak de Novi Pazar, Brecanovića pećina, a Gornjo Selo

Bathyscidius remyi Jeann.: LANeyrie, R., 1967, Ann. De Spéléologie. 22 (3), 611.

Bathyscidius remyi Jeannel, 1934: Pretner, 1968: Catalogus Faunae Jug. III. (6), 20.

Bathyscidius remyi Jeannel, 1934: Perreau, 2000: Mem. Sef, 4.: 193.

Bathyscidius remyi Jeannel, 1934: Perreau, 2004: Catalogue of Palaearctic Coleoptera. Vol 2:153.

Bathyscidius remyi Jeannel, 1934: Perreau, 2015: Catalogue of Palaearctic Coleoptera: 180-290.

Bathyscidius remyi Jeannel, 1934: Hlaváč, P., Perreau, M., Čeplík, D., 2017: Czhec Univ. of Life Csci, Pague, 100.

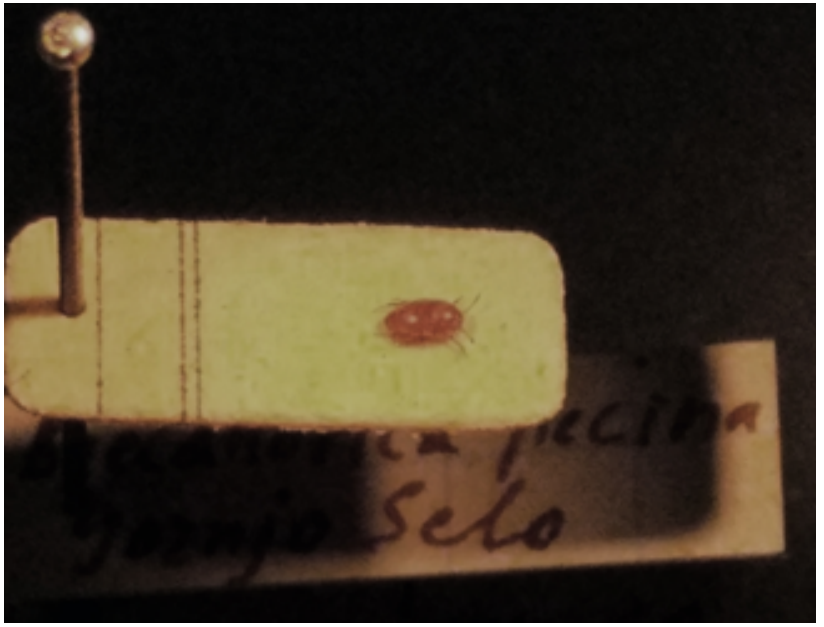

Fig. 94. Holotype female specimen of $B$. remyi = Laneyriella andrijevicensis in MNHN. (Photo: M. Perreau) 
René Jeannel (JEANNEL, 1934) described B. remyi based on single female collected on 30.08.1933 by M.P. Remy and M.R. Husson in a cave called Brecanovića pećina near Gornjo Selo, Sandjak de Novi Pazar in Northern Montenegro. (Type in MNHN).

The original description (translated from French) is follows: "Long $1.5 \mathrm{~mm}$. Reddish brown brilliant. Ovoid, very convex, the elytra almost "cuneiform", very attenuated on posterior side and very compressed laterally in the apical region, so that the suture is prominent, in carina. Short and recumbent pubescence. Strioles of elytra confused in the apical half. Short antennae, not reaching the posterior angles of the pronotum, of the same structure as in B. tristiculus, the clearly transverse article $8^{\text {th }}$. Pronotum broad and convex, its sides regularly arched, its widest width to the base. Elytra gradually narrowed from base to summit, without suture streak. Mesosternal keel is very high and very round, similar to that of other species of the genus. Male unknown. This species differs markedly from $B$. tristicula and B. tomoricensis in the form of elytra, its large size and its elytral strioles confused on the apical part. Its very short antenna separates it from $B$. tomoricensis. Perhaps it is closer to B. rambouseki Knirsch from the vicinity of Lake Ochrid, but in this species the $8^{\text {th }}$ antennomere is rounded and not transverse, which seems to be very characteristic".

After this description, no males or additional females were described. Type locality Velika Bracanovića pećina, cca $500 \mathrm{~m}$ SW from the village of Lubnice (Gornje selo) was visited by E. Pretner who set up pitfall traps and on 29.05.1968 collected two specimens, unfortunately both females. Similarly, on 31.07.1971, B. Deeleman collected an additional one female in the same cave. At the entrance of another cave Županska (Džupanska) pećina, which is in the close vicinity of Bracanovića pećina, we collected 7 specimens, among them males that turned out to be of the species Lanyriella andijevicensis (Jeannel, 1924). We checked the three females from Bracanovića pećina in the E. Pretner collection and they proved to be all females of $L$. andrijevicensis. M. Perreau (Paris) checked the holotype female specimen of B. remyi in MNHN. Unfortunately, according to present policy of the curatorship of the museum entomological collection, no type loan was allowed and no dissection was made. According to superficial morphological characters, checked on the dorsal and ventral site of the specimen by M. Perreau (Fig. 94) we conclude that the species B. remyi Jeannel 1934 is a new junior synonym for Laneyriella andrijevicensis (Jeannel, 1924).

Laneyriella andrijevicensis (Jeannel, 1924)

Figs. 4, 93.

Material Examined: HT: Brecanovića pećina, Gornjo Selo, Sandjak de Novi Pazar in Northern Montenegro, 30.08.1933, M.P. Remy \& M.R. Husson leg. (Type in MNHN). Montenegro, Berane, Mt Bjelasica, Lubnice, Velika Bracanovića pećina, 2 + , 29.05.1968, E. Pretner leg. (labelled as Bathyscidius remyi, E. Pretner det. 1976) (PMSL); Montenegro, Mojkovac, Mt Bjelasica, Biogradsko jezero, $1+$ 14.05.1964, E. Pretner leg., (Labelled as Pholeuonella andrijevicensis, E. Pretner det. 1976) (PMSL); Berane, Mt Bjelasica, Lubnice, Županjska pećina, 5 ỗ $\widehat{\jmath}$ \& 4 우우, 02.07.2007, Polak, S., \& Trontelj P., leg. (NMPO); Andrijevica, Komovi, 6 ô ô \& 
7 우, 02.07.2007, Polak, S., \& Trontelj P., leg. (NMPO); Mojkovac, Mt Bjelasica, Biogradsko jezero, 1 స̃, 02.07.2007, Polak, S., \& Trontelj P., leg. (NMPO);. Bijelo Polje, Korita, Sipanje, 3 ठ̂̉ \& 2 웅, 01.07.2007, Polak, S., \& Trontelj P., leg. (NMPO).

REDESCRIPTION OF THE FEMALE.

Size: Total body length (BL): $1.60-1.80 \mathrm{~mm}(\mathrm{~N}=4)$ in 9 +. Colour: Reddish brown, antenna and legs slightly paler. Antenna: (Fig. 93) Antenna length (AL): 0.627-0.630 $\mathrm{mm}(\mathrm{M}=0.629, \mathrm{~N}=4)$ in 9 ; $\mathrm{AL} / \mathrm{PL}: 1.13-1.17(\mathrm{M}=1.15)$ in $q$ \%.

AmL $\circ \circ: 0.072-0.072 ; 0.094-0.097 ; 0.059-0.059 ; 0.040-0.041 ; 0.041-0.042 ; 0.040-$ $0.040 ; 0.055-0.057 ; 0.033-0.034 ; 0.046-0.049 ; 0.049-0.049 ; 0.094-0.094(\mathrm{~N}=4)$.

AL/AmL (in \%) $+\circ: 11.46 ; 15.19 ; 9.39 ; 6.44 ; 6.60 ; 6.36 ; 8.91 ; 5.33 ; 7.56 ; 7.80 ; 14.96$ $(\mathrm{N}=4)$.

AmL/W + $0: 2.12 ; 2.89 ; 2.75 ; 1.84 ; 1.69 ; 1.51 ; 1.45 ; 0.94 ; 1.03 ; 0.86 ; 1.49$.

Pronotum: Transverse, concave with regularly rounded lateral edges, maximum width on posterior edge (Fig. 4). Dorsal face strongly pubescent with uniform short and decumbent pubescence, without order. PL: $0.535-0.558 \mathrm{~mm}$ $(\mathrm{M}=0.546, \mathrm{~N}=3)$ in $q$; ; PW: $0.890-0.957 \mathrm{~mm}(\mathrm{M}=0.920, \mathrm{~N}=3)$ in 9 ; ; Pronotum somewhat longer than in Bathyscidius species PL/PW 0.58-0.60 (M=0.59) in q 9 .

Thorax: Mesosternal carina well developed, elevated, moderately thick, on ventral edge flattened not lanceolate, extended over the metasternum, almost reaching the metasternal intercoxal apophysis (Fig. 4). Metendosternite and metatargal apparatus similar to species of the genus Bathyscidius (as in Figs. 9-11).

Elytra: Elytra elongate, not oval as in Bathyscidius spp. moderately narrowed toward the apex, subtriangular, very attenuate on posterior side and very compressed laterally in the apical region with maximum width on anterior part of elytra (Figs. 4, 94). Strongly pubescent with uniform short and decumbent pubescence inserted in strong lateral rows - transversal striae on elytra surface, obliterated toward the apex, without sutural carina. EL: 1.150-1.180 mm (M= 1.165, $\mathrm{N}=2)$ in $\circ \circ$; $\mathrm{EW}: 0.930-0.957 \mathrm{~mm}(\mathrm{M}=0.943, \mathrm{~N}=2)$ in 우; ratio $\mathrm{EL} / \mathrm{EW}$ : $1.23-1.24(\mathrm{M}=1.23)$ in 우.

Legs: Short and stout (Fig. 4) similar to that of species of the genus Bathyscidius (Figs. 5-8), more pubescent than in Bathyscidius. Male protarsi 5-segmented, strongly dilated, female protarsi 4-segmented, not dilated with exception of first article, which is slightly wider than others (Fig. 4). Lateral side of protibia in both sexes armed with a distinct comb of flat spines, which are limited to the first apical third of the protibia and not as strong as in Bathyscidius. On apex two polident spurs are present, as in genus Bathyscidius. PtarL: 0.206-0.210 (M=0.208, $\mathrm{N}=3) \mathrm{mm}$ in $q$; ; PtarW: 0.033-0.034 (M=0.034, N=3) mm wide in $q$, (strongly

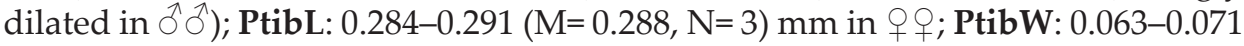
$(\mathrm{M}=0.067, \mathrm{~N}=3) \mathrm{mm}$ wide in $\circ$ ㅇ․

Female genitalia: Female ventrite VIII strongly haired on proximal part with anterior stout or slim apophysis of medium length, similar to species of the genus Bathyscidius (as in Figs. 14). Urite IX different than in Bathyscidius, with narrow and slim stylomeres. Sub-gonocoxite with one stylus, gonocoxite with one basal, one lateral and two subapical styles, gonostylus with one longest stylus. 
Spermatheca sack-like or sausage-like, curved, uniformly and weakly sclerotized, rounded, similar to species of the genus Bathyscidius. Hyaline gland attached to the spermathecal duct at the proximal part of spermatheca, similar to species of the genus Bathyscidius.

\section{Bathyscidius (Pseudobathyscidius) serbicus Karaman 1964 = Pseudobathysci- dius serbicus (Karaman 1964) comb. nov.}

Bathyscidius (Pseudobathyscidius) serbicus Karaman, 1964, Bull. soc. entomol. Mulhouse, (2): 30. lct : Siberie [Serbie] orientale, environs de Zaječar

Pseudobathyscidius serbicus Z. Karaman: V. B. Guéorguiev, 1974, C. R. Acad. Bulg. Sci., 27 (6): 841.

Pseudobathyscidius serbicus Z. Karaman: V. B. Guéorguiev, 1976, Razprave Sazu, 19 (4): 14, 48

Pseudobathyscidius serbicus Karaman 1964: Nonveiller, 1981, Acta entomol. Jugosl., 17 (1-2): 153.

Pseudobathyscidius serbicus Karaman 1964: Newton, 1998: Atti Museo Reg. di Scienze Natur., Torino, 127.

Pseudobathyscidius serbicus Karaman 1964: Perreau, 2000: Mem. Sef, 4.: 193.

Bathyscidius serbicus Karaman, 1964: Giachino, 2005 (2006): Riv. Mus. civ. Sci. Nat., Bergamo, 24 [2005]: 15.

Pseudobathyscidius serbicus Karaman 1964: Perreau, 2004: Catalogue of Palaearctic Coleoptera. Vol 2:154.

Pseudobathyscidius serbicus Karaman1964: Perreau, 2008, Inst. Nat. prot. Serbia, Monogr., 22: 179-180.

Pseudobathyscidius serbicus Karaman 1964: Perreau, 2015: Catalogue of Palaearctic Coleoptera: 180-290.

Pseudobathyscidius serbicus Karaman 1964: Hlaváč, P., Perreau, M., Čeplík, D., 2017: Czhec Univ. of Life Csci, Pague, 101.

Pseudobathyscidius serbicus Karaman 1964: Perreau, 2019, Zootaxa 4590 (3): 367-381.

Zora Karaman (Karaman, 1964) described Bathyscidius (Pseudobathyscidius) serbicus from the surroundings of Zaječar in Eastern Serbia and established a new subgenus Pseudobathyscidius Karaman 1969 for this species. Guéorguiev (1976) elevated the subgenus Pseudobathyscidius to the rank of genus but later (Giachino, 2005) synonymized this genus. Perreau (2008) discussed as very improbable the synonymy with Bathyscidius suggested by Giachino (2005) and suggested the status of Pseudobathyscidius as a separate genus again, but he does not formally declare the new combination in the paper.

According to the morphological characters described in the original description by KARAMAN (1964), namely antennomere proportions, lack of evident transversal striae on elytra, shape of mesosternal carina (according to illustration in original description), that reaches mesocoxa i.e. middle part of metasternum but does not extend over the metasternum (almost reaching the metasternal intercoxal apophysis) and especially the aedeagus characters, curved in lateral view, short basal lamina and some sclerotized structures in the basal part of internal sack of median lobe resembling the "Y piece", the species Bathyscidius serbicus deserves the ranking of a separate genus, Pseudobathyscidius, as proposed by GuÉorguiev (1967). So here, we propose formally again a new combination i.e., the justification of Pseudobathyscidius as a separate genus in concordance with GuÉorguiev (1967) and Perreau $(2008,2019)$. 


\section{Identification key to the species of the genus Bathyscidius Jeannel 1910}

Identification key for the genus Bathyscidius is based on the lengths of antennomeres in females and males, the distinctive aedeagus shape and proportions in males and female genital parts. The key requires morphometric measurements.

Cavernicolous or endogeic small-sized Leptodirini $1.27-1.70 \mathrm{~mm}$ in length, distributed along the south-eastern Adriatic coast, in south-eastern Albania and south-western Northern Macedonia. Pubescence on elytra aligned in transversal striae. Mesosternal carina well developed, elevated, on posterior side the sharp beak of carina extended over the metasternum, almost reaching the metasternal intercoxal apophysis. Protarsi with four segments and not dilated in either sex. Protibias on the external lateral and apical side with the row of flattened spines, equally long, forming a comb (pecten). Aedeagus relatively small, inner sac without visible sclerotized structures. Parameres straight, parallel with a median lobe, shorter than the median lobe. Paramere apex armed with three erected setae similar in size and length.

Bathyscidius (Jeannel).

1 Aedeagus elongated, small $0.29-0.34 \mathrm{~mm}$ long, median lobe basal lamina relatively short, shorter than 29.0 \% of aedeagus length (Figs. 65-72). Paramera apex with one apical erected and two subapical long setae oriented toward the median lobe, similar in size and length (Fig. 61). Female urite IX (genital segment-ovipositor) stylomeres with straight outer and moderately convex inner edge (Fig. 63) . ............................................................................

1'Aedeagus elongated, bigger $0.37-0.41 \mathrm{~mm}$ long, median lobe basal lamina prolonged, longer than $29.5 \%$ of aedeagus length (Figs. 73-78). .5

2 Aedeagus median lobe in dorsal view slender, narrow lanceolate, slightly widened on its apical third. Index Aedeagus length/Median lobe Max. width $>$ 6.5. Median lobe apical tip moderately sub-oval (Figs. 65-68).

2' Aedeagus median lobe in dorsal view less narrow, lanceolate, significantly widened on its apical third. Index Aedeagus length/Median lobe Max. width < 5.6. Median lobe apical tip moderately sub-triangular (Figs. 69-72).

3 Larger body size, total body length (BL): 1.38-1.61 mm in $\widehat{\partial} \delta^{\lambda}$ and $1.40-1.72 \mathrm{~mm}$ in 9 우. Ratio of Aedeagus L/Median lobe Max. W 6.5-7.5. Antenna longer, 0.59

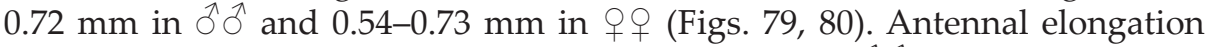
index (Antenna L/Pronotum L) 1.28-1.33 (M=1.29) in गे के and 1.13-0.23 (M= 1.20 ) in 90 . Antennomeres $8^{\text {th }}, 9^{\text {th }}$ and $10^{\text {th }}$ equally as long as wide or slightly longer. tristiculus (Apfelbeck)

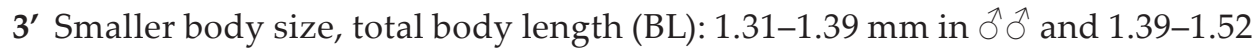
$\mathrm{mm}$ in 9 우. Ratio of Aedeagus L/Median lobe Maximal W 7.4-8.3. Antenna shorter 0.51-0.59 in $\widehat{\delta} \widehat{\delta}$ and 0.52-0.58 in 우 (Figs. 81, 82). Antennal elongation index (Antenna L/Pronotum L) 1.23-1.27 $(\mathrm{M}=1.25)$ in $\widehat{\partial} \widehat{\partial}$ and $1.18-1.21(\mathrm{M}=1.19)$ in $q+$. Antennomeres $8^{\text {th }}, 9^{\text {th }}$ and $10^{\text {th }}$ significantly shorter than wide mljetensis sp. n. 
4 Larger body size, total body length (BL): 1.46-1.50 mm in $\hat{\jmath} \hat{~}$ and 1.60-1.64 $\mathrm{mm}$ in 9 . . Ratio Aedeagus L / Median lobe Max. W 5.3-5.6. Antenna shorter, $0.576-0.589 \mathrm{~mm}$ in $\widehat{\partial} \widehat{\partial}$ and $0.585-0.602 \mathrm{~mm}$ in $\circ$ 우 (Figs. 83, 84) Antenna slightly longer than pronotum length, antennal elongation index (Antenna L/Pronotum L) 1.24 in $\partial^{\lambda}$ and 1.16 in +9 . Antennomeres $8^{\text {th }}, 9^{\text {th }}$ and $10^{\text {th }}$ significantly shorter than wide .fallaciosus Müller

4' Smaller body size, total body length (BL): $1.42-1.52 \mathrm{~mm}$ in $\widehat{\partial} \hat{\sigma}$ and $1.45-1.57$ $\mathrm{mm}$ in $ᄋ$ 우. Ratio Aedeagus L / Median lobe Maximal W 5.0-5.4. Antenna longer, $0.700-0.749 \mathrm{~mm}$ in $\widehat{\partial} \widehat{\partial}$ and $0.712-0.765 \mathrm{~mm}$ in $q$ Q $($ (Figs. 85, 86). Antenna significantly longer than pronotum length, antennal elongation index (Antenna

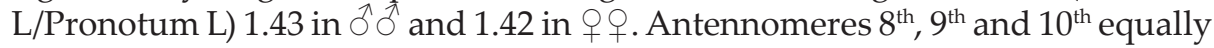
as long as wide or longer.

komajiensis sp. n.

5 Aedeagus median lobe in dorsal and lateral view wide, cylindrical, basal lamina wide and relatively long (Figs. 77, 78). Index Aedeagus L / Median lobe Maximal W 4.3-5.5. Paramere apex armed with three erected, one apical straight long seta and two subapical long setae oriented toward the median lobe similar in size and length. Antennomeres $8^{\text {th }}, 9^{\text {th }}$ and $10^{\text {th }}$ significantly shorter as wide. Female urite IX (genital segment-ovipositor) stylomeres with straight outer and moderately convex inner edge (Fig. 63). orjensis sp. n.

5' Aedeagus median lobe in dorsal and lateral view narrow, elongated, dorsolaterally flattened, basal lamina wide and relatively long (Figs. 73-76). Median lobe apex rounded at the end, gradually tapered (subtriangular) with rounded, not pointed tip. Paramere apex armed with three subapical long erected setae of similar in size and length. Female urite IX (genital segment-ovipositor) stylomeres with concave outer and straight or moderately convex inner edge (Fig. 64).

6. Ionobathyscidius subgenus nov.

6 Aedeagus median lobe in dorsal and lateral view extremely elongated, lanceolate, basal lamina extremely long (Fig. 73, 74). Index Aedeagus L / Median lobe Maximal W 8.4-9.8. Median lobe rounded at the end slowly narrowed (subtriangular) with rounded, not pointed tip. tomoricensis Müller

6' Aedeagus median lobe in dorsal and lateral view lanceolate, basal lamina shorter (Fig. 75, 76) Index Aedeagus L / Median lobe Maximal W 6.8-7.1. Median lobe apex rounded at the end abruptly tapered with rounded, not pointed tip. Median lobe in the apical part with two lateral dorsally curved longitudinal lobes.

rambouseki Knirsch

\section{DISCUSSION}

The genus Bathyscidius is one of the smallest of the leptodirines. Such small leptodirines are mostly edaphobionts i.e. live in forest leaf litter and the upper parts of soil, "muscicoles" in French and in some works (VANDEL, 1965). The species B. rambouseki and B. tomoricensis can be found in such leaf litter habitats, soil or under deeply embedded stones, even in summer months. The type localities of B. rambouseki and B. tomoricensis are situated on Mt Galičica and Mt Tomori, respectively, at higher elevations, within leaf litter habitats. In such altitudes, the climatic conditions are expected to be more humid and not very dry in summer 
periods, unlike the usual situation in Mediterranean forested environments. $B$. rambouseki and $B$. tomoricensis have similar body sizes and antenna length proportions i.e. short antenna, mostly not protruding over the pronotum posterior edge, characteristic for edaphobiontic leptodirines.

Similarly, the newly found and described species, B. orjensis sp. n., is of similar body proportions. Unlike the previous species, it was not found in leaf litter habitat in the forest but in humid black soil among the rock crevices on the base of a small calcareous hill. The hill near the village of Kruševice is isolated in the middle of a flat valley, filled with fluvioglacial sediments in consequence of he Pleistocene glaciation of Mt Orjen (Komar, 1995). The locality on the southern slope of Orjen, at an altitude of ca $750 \mathrm{~m}$ a.s.1., is otherwise in a relatively dry area with a strong sub-Mediterranean influence (Fig. 60). The microhabitat of B. orjensis $\mathrm{sp} . \mathrm{n}$. is characterised by its having a cooler environment than the surroundings, due to the cold airflow that can be detected also in the summer time. The situation indicates that there is some subterranean environment beneath the exact finding locality. A similar environment, characterized by rock crevices accompanied with strong and cold airflows are known from many places in Orjen, and are called "puvaljka" in the local language. Sometimes, "puvaljke" are used by locals for cooling water and food during summer fieldwork (G. Culafić, personal comm.). The terrestrial subsurface habitats, often occurring in the vicinity of caves, and he superficial zone of rock fissures and even rock debris slopes are scientifically known as Shallow Subterranean Habitats - SSH (Culver \& Pipan, 2009; 2014). Special terrestrial type of such SSH, was originally described as Milieu Souterrain Superficiel - MSS (Juberthie et al., 1980) and translated to English as the Superficial Underground Compartment or Mesovoid Shallow Substratum (Culver \& Pipan, 2009). MSS, which is the mostly used term among entomologists, generally occurring at the junction of the soil and rock layer at a depth of one to few meters, consists of a system of micro places among the rocks and must be covered by soil (Culver \& Pipan, 2014). It is generally found in mountains of the temperate zones, but in the Mediterranean environment as well (Giachino \& Vailati, 2010). Since the exact borders among the leaf litter, soil, MSS and caves are thin and since subterranean fauna show some seasonal vertical migration among these habitats (PiPAn et al., 2011; PolaK, 2012) the exact primary habitat of B. orjensis sp. n. cannot be yet defined.

In contrast, the rest of the known Bathyscidius species distributed along the Adriatic coast are found in deeper subterranean environments, at cave entrances and in caves. They share adaptations to the subterranean habitats such as less pubescent teguments and exhibit significantly longer antenna. To a certain degree, this can be considered an adaptation to the subterranean life style (JEANNEL, 1911; 1924). Since the leaf litter and upper parts of the soil in the Mediterranean area in summer time usually suffer exceptional droughts, the cave environments can be considered as probable refugia for at least some of Bathyscidius species.

It is generally accepted that edaphobitic species of leptodirini have better dispersal abilities and have thus wider ranges. The species of the genera Pholeuonella, Laneyriella and Phaneropella present in the same region as Bathyscidius and are found in leaf litter habitats, occupying wider ranges (PrETNER, 1968; 1973; 
1977). By contrast, the Bathyscidius species are known from a single cave or just couple of caves in a small area. Observing some other internal morphological structures as metendosternite, which is narrow and not similar to that in typical leaf litter species as Bathyscia sp., Bathysciola sp. or Phaneropella lesinae, and especially the metatergal apparatus which is reduced and not broad winged as in the mentioned genera, we can consider the genus Bathyscidius to be rather primarily cavernicolus than edaphobitic. Adaptations to life in edaphic habitats in some Bathyscidius species as B. orjensis or B. rambouseki can, therefore, be considered to be secondary lifestyle adaptations. That is another example of the small bathyscioid habitus not necessarily meaning that taxa are not specialized, as has been demonstrated by Vailati (1988) in the case of some Boldoria and Cryptobathyscia from the Italian Alps.

Excluding synonymized species as B. remyi and B. (Pseudobathyscidius) serbicus, from the genus, the range of the rest of the species in the subgenus Bathyscidius s. str. is small and geographically comprehensive, including the Dalmatia coastal regions southern from Pelješac to Mt Orjen in Montenegro. The distributions of $B$. rambouseki and B. tristiculus are rather remote and isolated from others. The morphological characters we describe in the description of the subgenus Ionobathyscidius support the probable genetic isolation and split of the genus into two subgenera groups of species. Such geographical and ecological separations can be result of Pleistocene events in the region i.e., the glaciation of the high

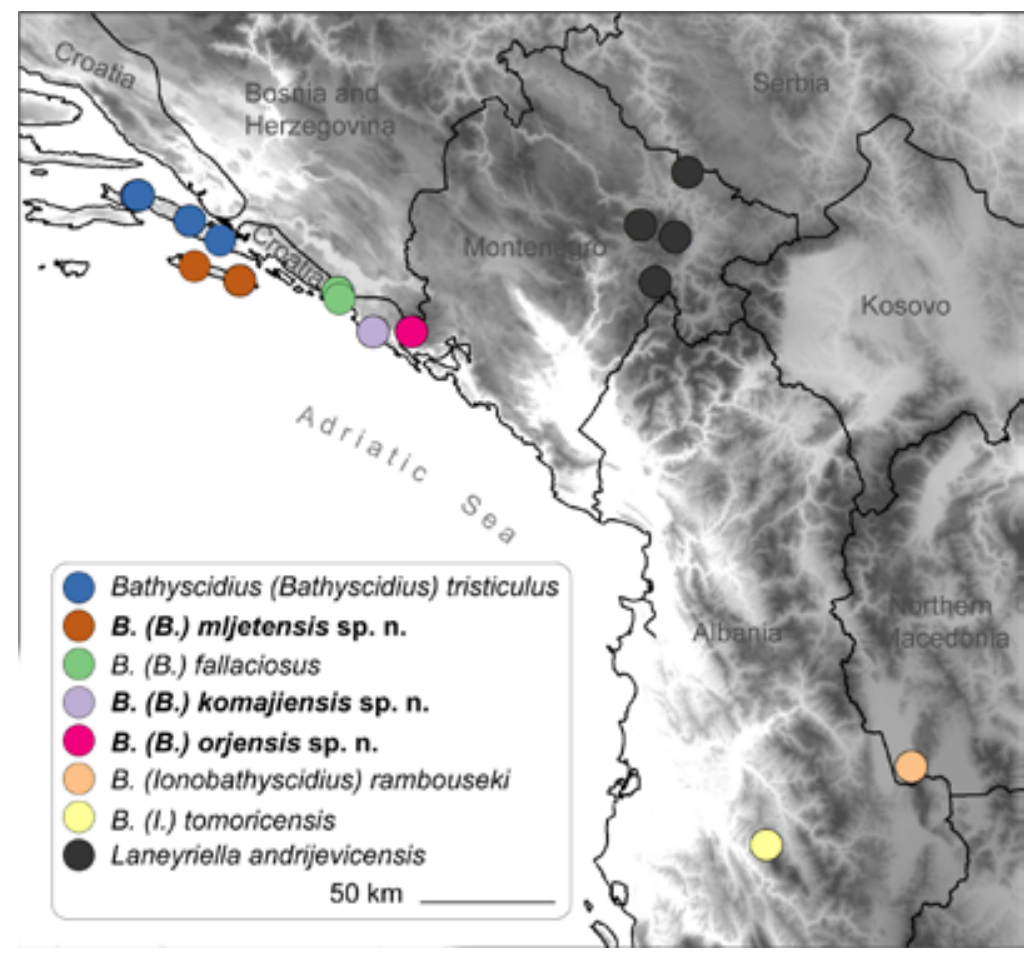

Fig. 95. Distribution map of known localities of the genus Bathyscidius and Laneyriella andrijevicenis. 
mountain ranges in the past. However, this remains at the level of hypothesis and only the forthcoming molecular analyses will clarify the phylogenetic relation of the focal taxa and their evolutionary development.

Cave adaptations in species of Bathyscidius s. str. and patterns of their geographical and geological isolation can also be used as a promising tool in prediction of the discovery of new species. Based on previous findings, new species can be expected in the coastal region of Southern Dalmatia, assuming, of course, vigorous collecting efforts and considerable amount of luck. During the searching for the B. tristiculus type locality, the small cave near Janjina on Pelješac peninsula, Croatian speleobiologists investigated numerous cave objects without recording any presence of Bathyscidius specimens. A single male specimen collected recently and studied from Špilja kod vrha Splie near Polače on the western part of Mljet island fits with $B$. mljetensis sp. $\mathrm{n}$. in its body proportions and aedeagus shape but has slightly shorter antennae. The exact meaning of this difference is not validated in the present study, but we cannot exclude the possibility that this specimen (along with its population), forms an isolated geographical race, a subspecies or even a separate species. Nevertheless, since additional specimens need to be collected and studied, the position of this specimen within B. mljetensis sp. $\mathrm{n}$. is only provisional. By contrast, it is to be expected that only one species, $B$. orjensis sp. n., exists in the wider Orjen Mountain area. Surrounding mountain ranges such as Krivošije and Sniježnica in Croatia are promising as well, especially, since this species, it is believed, lives in the MSS habitat and has better dispersal possibilities. We expect, based on habitat preferences, that focused studies on MSS habitats will reveals significantly larger distribution ranges for edaphic species of Bathyscidius, B. rambouseki and B. tristiculus. Similarly, the new taxa from the subgenus Ionobathyscidius from other less investigated places in southern Albania, south-western parts of Northern Macedonia and North Greece will probably be found. The great subterranean biodiversity of leptodirines recently found in MSS habitats in Greece is promising and already reported by Giachino \& Vailati (2010).

The use of modern molecular phylogenetic techniques is at this point urgent so as to clarify the organic higher systematics of the studied leptodirines. The genus Bathyscidius is at present knowledge listed in tribus Bathysciae, Group Théléomorphes and division III according to JEANNEL (1924) and in subtribe Bathysciotina according to Guéorguiev (1974, 1976). Subtribe division on the Supraflagellates and Infraflagellates according JeAnnel (1955), Giachino et al. (1998) and CAsAle et al. (1991) is ambiguous since Bathyscidius has not sclerotized structures or dorsal flagellum in the aedeagus inner sac at all. Supra-generic position of the genus Bathyscidius is thus confusing and has not been studied or discussed in this genus revision.

\section{ACKNOWLEDGEMENTS}

We are grateful to Peter Trontelj (Ljubljana), Helena Bilandžija (Zagreb), Miloš Pavićević (Podgorica) who accompanied us during field collections and Lara Jogan Polak (Ljubljana) for support during long field excursions. We want to 
thank to the participants of the 2nd Biospeleological expedition - Pelješac 2019, namely the leaders, Nikolina Kuharić and Alen Kirin, as well as other members of Croatian Biospeleological Society, Speleološki odsjek HPD Sniježnica from Dubrovnik and Marijana Miljac Đuračić for their support. Special thanks to the guides for their willingness, enthusiasm and help in the field; without them many caves and pits on the island would have remained forgotten. In alphabetical order they are: Osvin Pečar, Damjan Aljinović, Martina Aljinović, Jakov Nodilo, Ante Rogulj, Baldo Hazdovac, Nikola Hazdovac, Vicko Zvone, Marija and Željko Hazdovac, Pero Hazdovac, Marijo Franić, Nikola Sršen, Ivan Sršen, Vid Radulj, Dragan Dabelić and Davor Stražičić. We are grateful to Tonči Rađa (Split), Petra Bregović (Varaždin) for furnishing some additional specimens studied in the revision. Snežana Dragićević (Podgorica) helped us to obtain permits to collect specimens in Montenegro and in some text improvements. We are further deeply indebted to Andrea Colla (Trieste) for enabled us to study topo-type specimens of B. tomoricensis from Natural History Museum of Trieste (Italy) and Michel Perreau who has-checked the type specimen of B. remyi in Collection of Entomological department of the National Museum of Natural History (MNHN) in Paris (France). Jasminko Mulaomerović (Sarajevo) and Tonći Rađa (Split) and Snežana Dragićević (Podgorica) provided us with requested literature. Tamara Čuković gave us B. mljetensis photographs taken in its natural habitat. Finally, we wish to thank Teo Delić (Ljubljana) for some critical draft text improvements and for elaborating the taxa distribution map for this paper.

Received September 2, 2019

\section{REFERENCES}

Apfelbeck, V., 1905: Paeinsulae balcanicae coleopterum species novae. Glasnik zemaljskog muzeja u Bosni i Hercegovini, 17, 245-251.

Culver, D. C. \& Pipan, T., 2009: The Biology of Cases and Other Subterranean Habitats.Oxford University press, Inc. New York, $254 \mathrm{pp}$.

Culver, D. C. \& Pipan, T., 2014: Shallow Subterranean Habitats. Ecology, Evolution, and Conservation. Oxford University Press, Oxford, 257 pp.

Čirčić, B. P. M., Makarov, S., E., RaĐA, T., Ilić, B. S. \& D. Ž. Antić, 2012a: Roncus meledae n. sp. and Neobisium oculatum n. sp., from the Island of Mljet, Dalmatia (Neobisidae, Pseudoscorpiones). Arch. Biol. Sci., Belgrade 64(4), 1567-1576.

Ćuričić, B.P.M., RaĐA, B., Dimitrijević, R.N. \& ĆurČIĆ, S.B., 2012b: On two new cave pseudoscorpions from Dalmatia, Croatia (Chthoniidae and Neobisiidae, Pseudoscorpiones). Arch. Biol. Sci. Belgrade 64(3), 1099-1108.

Fresneda, J., Grebennikov, V.V. \& Ribera, I., 2011: The phylogenetic and geographic limits of Leptodirini (Insecta: Coleoptera: Leiodidae: Cholevinae), with a description of Sciaphyes shestakovi sp. n. from the Russian Far East. - Arthropod Systematic \& Phylogeny 69(2), 99-123.

Giachino, P.M., 2005 (2006): Bathyscidius comottiorum N. Sp. del Kosovo (Coloptera, Cholevidae, Leptodirinae). Rivista del Museo Civico di Scienze Naturali “Enrico Caffi”, Bergamo, 24, 11-15.

Giachino, P.M. \& Vailati, D., 2010: The Subterranean Environment. Hypogean life, concepts and collecting techniques. WBA Handbooks, Verona, 3, $132 \mathrm{pp}$.

Giachino, P.M., Vailati, D. \& CASAle, A., 1998: Major questions in the phylogeny and biogeography of Cholevidae (Coleoptera), with emphasis on the subfamily Leptodirinae. Pp. 179-120 in: Giachino P.M. \& Peck S.B. (eds), Phylogeny and Evolution of Subterranean and Endogean Cholevidae (= Leiodidae Cholevinae). - Proceedings of a Symposium (30 August, 1996, Florence, Italy) at XX 
International Congress of Entomology. Atti Museo Regionale di Scienze Naturali. Torino.

GuÉorguiev, V.B., 1976: Recherches sur la taxonomie, la classification et la phylogénie des Bathysciinae (Coleoptera: Catopidae). - Razprave SAZU, Ljubljana 19(4), 91-129.

Hlaváč, P., Perreau, M. \& Čeplík, D., 2017: The Subterranean Beetles of the Balkan peninsula. Czech University of Life Sciences, Faculty of Forestry and Wood Sciences, Department of Forest Protection and Entomology, Praha, 267 pp.

Jalžić, B., Bedek, J., Bilandžıja, H., Bregović, P., Cvitanović, H., Čuković, T., Ćukušić, A., Dražina, T., Đud, L., Gottstein, S., Hmura, D., Kljaković Gašpić, F., KomeričKi, A., Kutleša, P., Lukić, M., Malenica, M., Miculinić, K., Ozimec, R., Pavlek, M., Raguž, N., Slapnik, R. \& Štamol, V., 2013: Atlas špiljskih tipskih lokaliteta faune Republike Hrvatske, svezak 2. Hrvatsko biospeleološko društvo, Zagreb. pp. 238.

JANJANIN, Ž., 2019: Istraživanje jame Bezdan - Konavle 2017. Subterr. Croat. 17, 26(1), 21-25.

Jeannel, R., 1911: Biospelologica. XIX. Révision des Bathysciinae (Coléoptères Silphides). Monographie; distribution géographique, systématique. Archives de Zoologie Expérimentale et Générale 47(1), 641 pp.

Jeannel, R., 1924: Monographie des Bathysciinae. Archives de Zoologie Expérimentale et Générale 63(1), 434 pp.

Jeannel, R., 1934: Bathysciinae recueillis par MM. P. Remy et R. Husson dans le Sandjak de Novi Pazar et la Macédoine grecque. Revue française d'Entomologie 1(1), 89-103.

JeAnnel, R., 1910: Essai d'une nouvelle classification des Silphides cavernicoles. Archives de Zoologie expérimentale et générale 45(1), 1-48.

Juberthie, C., Delay, B. \& Boulllon, M., 1980: Extension du milieu souterrain en zone non-calcaire: description d'un nouveau milieu et de son peuplement par les coléoptères troglobies. Mémoires de Biospéleologie 7, 19-52.

Karaman, Z., 1964: Nouvelle espèce de Bathyscidius de Sibérie orientale, et remarques sur l'expansion de l'espece myrmécophyle Reitteria balcanica Karaman. Bulletin de la Société entomologique de Mulhouse (2), 30-33.

KNIRsch, E., 1931: Zwei neue von Dr. Fr. Rambousek in Mazedonien gesammelte Bathysciinae (Col.). Časopis Československé Společnosti Entomologické 28(1-2), 2-4.

Komar, G., 1995: Orjenski masiv. Herceg Novi. pp. 290

Laneyrie, R., 1967: Nouvelle classification des Bathysciinae (Coléoptères Catopidae). Annales de Spéléologie 22(3), 645 pp.

MülleR, J., 1911: Zwei neue Höhlensilphiden aus den österreichischen Karstländern. - Wiener Entomologische Zeitung 30(6-7), 175-176.

Müller, J., 1910: Diagnosen neuer Höhlensilphiden. Zoologische Anzeiger 36(8/9), 184-186.

MüLleR, J., 1917: Systematisch-faunistische Studien über Blindkäfer. Sitzungsberichte der Akademie der Wissenschaften in Wien. Mathematisch-naturwissenschaftliche Klasse 126(8), 607-656.

Müller, J., 1922: Risultati scientifici della spedizione Ravasini-Lona in Albania. Anoftalmi e Silfidi ciechi I., Estrato dal Bolletino della Società entomologica italiana 54, 87-91.

Newton, A.F., 1998: Phylogenetic problems, current classification and generic catalog of world Leiodidae (Including Cholevidae). Pp. 41-178 in: Giachino P.M. \& Peck S.B. (eds.), Phylogeny and Evolution of Subterranean and Endogean Cholevidae (= Leiodidae Cholevinae). - Proceedings of a Symposium (30 August 1996, Florence, Italy) at XX International Congress of Entomology. Atti Museo Regionale di Scienze Naturali. Torino.

Ozimec, R., Rnjak, G., Jalžić, B., Lacković, D., Cvitanović, H., Basara, D., Kovačević, A., Polić, G., Grgurev, M., Hanžek, N., Rade, P., Kljaković-Gašpić, F. \& O. Antonić, 2015: Spelaeologia Ragusina 1: Katastar speleoloških objekata, podzemnih građevina, krških izvora I krških bunara kopnenog dijela Dubrovačko-neretvanske županije. Subterranea Croatica 13, suppl. 1, 1-152.

Perreau, M., 2000: Catalogue des Coléoptères Leiodidae Cholevinae et Platypsyllinae. - Mémoires de la Société Entomologique de France 4, 469 pp.

Perreau, M., 2004: Leiodidae, 133-203; in Löbl, I. \& Smetana, A. (eds): Catalogue of Palearctic Coleoptera, Vol. 2 (Hydrophiloidea - Histeroidea - Staphylinoidea). Stenstrup: Apollo Books, 942 pp.

Perreau, M., 2008: Pavicevicia N. Gen., a new Genus with one new species of Bathyciotina from Kosovo (Coleoptera, Leiodidae, Cholevinae, Leptodirini). Advances in studies of the fauna of the Balkan Peninsula. Papers dedicated to the memory of Guido Nonveiller, Institute for Nature 
Conservation of Serbia, Belgrade. Monograph 22, 177-182.

Perreau, M., 2015: Leiodidae, 180-290 - in LöBL, I. \& LöвL, D. (Eds.): Catalogue of Palearctic Coleoptera. (Hydrophiloidea - Staphylinoidea). Revised und Updated Edition. Brill: Leiden, Boston.

Perreau, M., 2019: Phylogeny of Bathysciotina Guéorguiev, 1974, based on morphology with a special emphasis to Italian genera and with the description of a new species of Halbheria (Coleoptera Leiodidae Cholevinae Leptodirini). Zootaxa 4590(3), 367-381.

Pipan, T., López; H., Oromí; P., Polak; S. \& Culver, D.C., 2011: Temperature variation and the presence of troglobionts in terrestrial shallow subterranean habitats. Journal of Natural History 45(3-4), 253-273.

PoLAK, S., 2012: Vertical migration of the subterranean beetles as a respond to annual temperature fluctuations. $21^{\text {st }}$ International Conference on Subterranean Biology (ICSB). 02.- 07. september 2012, Košice, Slovakia, Book of Abstracts p. 90.

Pretner, E., 1968: Catalogus Faunae Jugoslaviae, Coloptera: Catopidae: Bathysciinae. Slovenska akademija znanosti in umetnosti, 3(6), 59 pp.

Pretner, E., 1973: Koleopterološka fauna pećina i jama Hrvatske s historijsim pregledom istraživanja. Krš Jugoslavie, Jugoslovanska akademija znanosti i umjetnosti 8(6), 101-239.

Pretner, E., 1977: Pregled podzemne faune koleoptera Crne Gore. - The Montenegrian Academy of Sciences and Arts, Glasnik 2, 91-186.

Vailati, D., 1988: Studi dui Bathysciinae delle Prealpi centro-occidentali. Revisione sistematica, ecologia, biogeografia dell "serie filetica di Boldoria" (Coleoptera Catopidae). Monografie di "Natura Bresciana" 11, 1-331.

Vandel, A. 1965: Biospeleology. The Biology of Cavernicolous Animals. Pergamon Press. Ltd. Oxford / London. 524 pp.

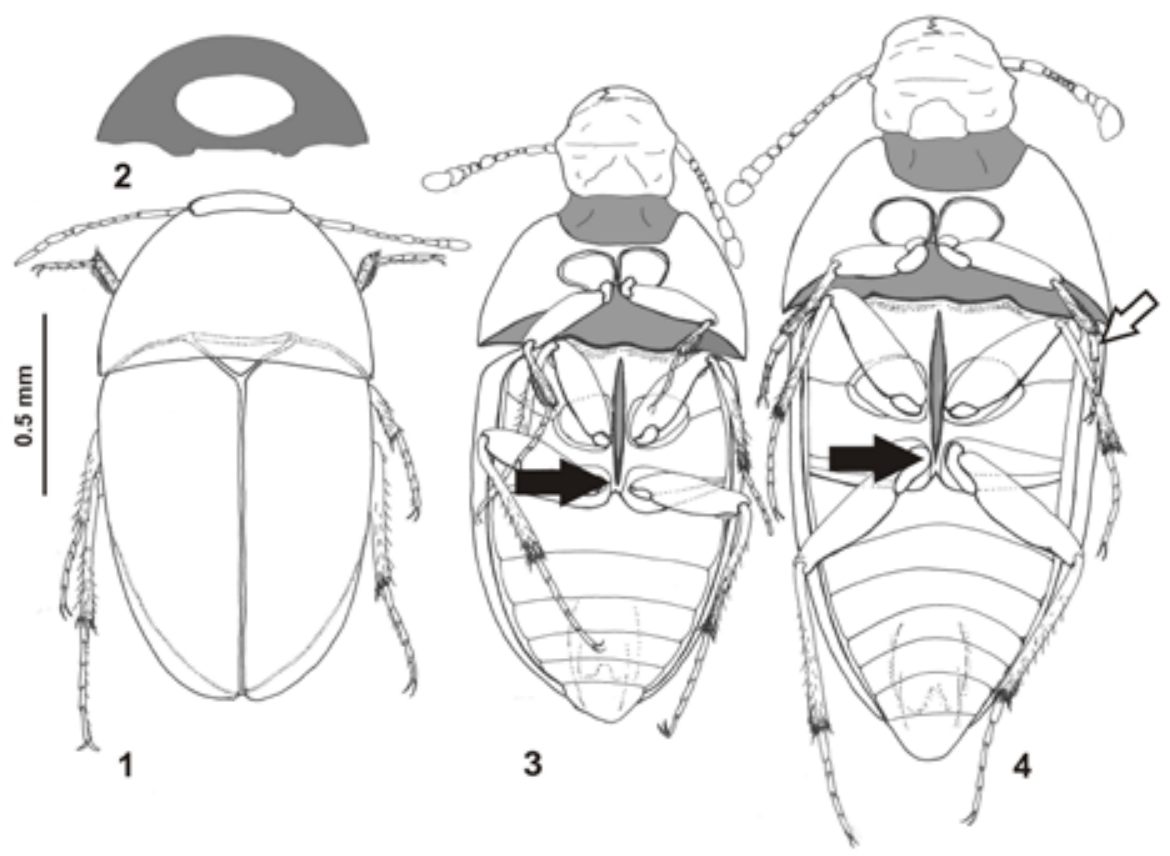

Figs. 1-4. Dorsal and ventral habitus: 1: Bathyscidius fallaciosus Müller, $q$ dorsal side. 2: B. fallaciosus Müller, o pronotum, apical view- cross-section. 3: B. fallaciosus Müller, o ventral side. 4: Laneyriella andrijevicensis (Jeannel), $q$ ventral view (black arrow indicates mesosternal carina proximal beak extension over the metasternum, white arrow indicates widened first protarsomere in Laneyriella). 


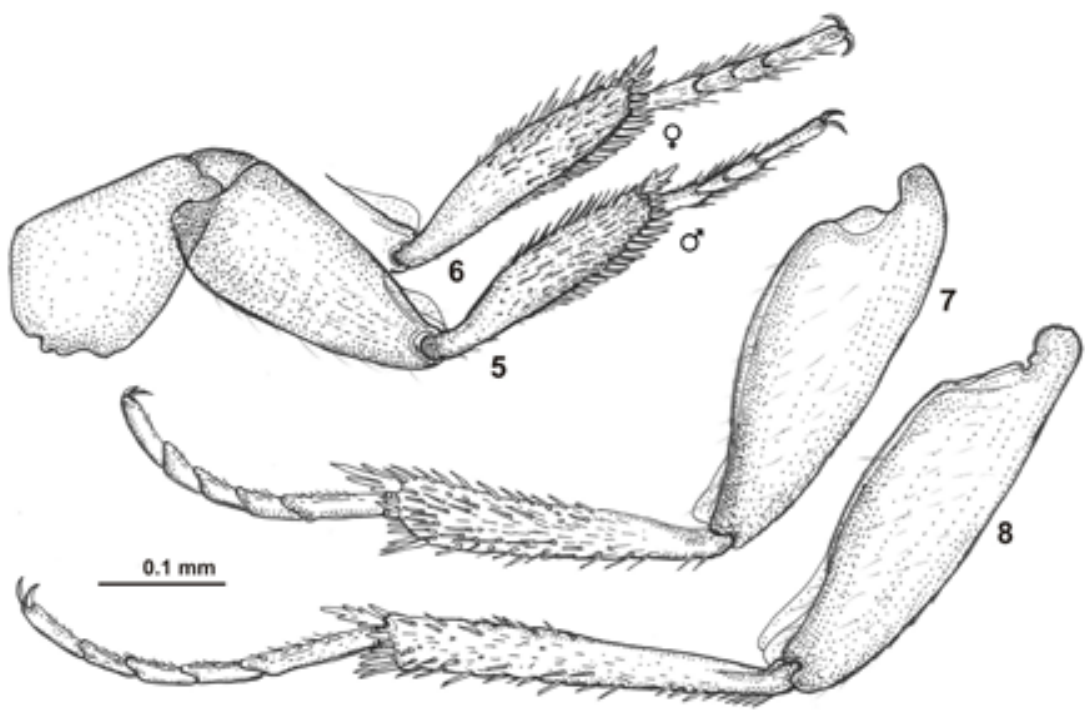

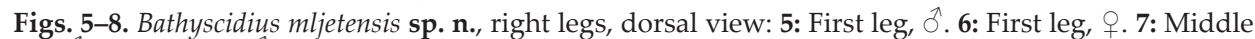

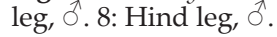

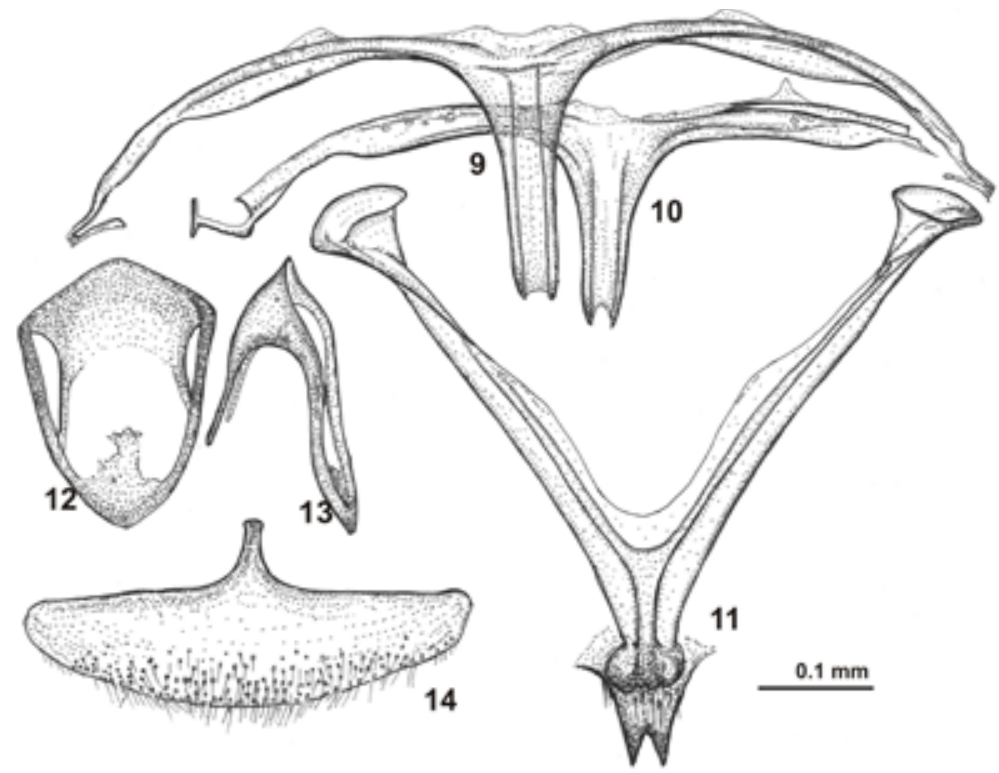

Figs. 9-14. Bathyscidius sp. internal structures: 9: Bathyscidius mljetensis sp. n., Metatergal apparatus. 10: Bathyscidius orjensis sp. n., Metatergal apparatus. 11: Bathyscidius fallaciosus, metendosternite. 12: Bathyscidius orjensis sp. n., male genital segment, dorsal view. 13: Bathyscidius orjensis sp. n., male genital segment, lateral view. 14: Bathyscidius fallaciosus, female ventrite VIII, dorsal view. 


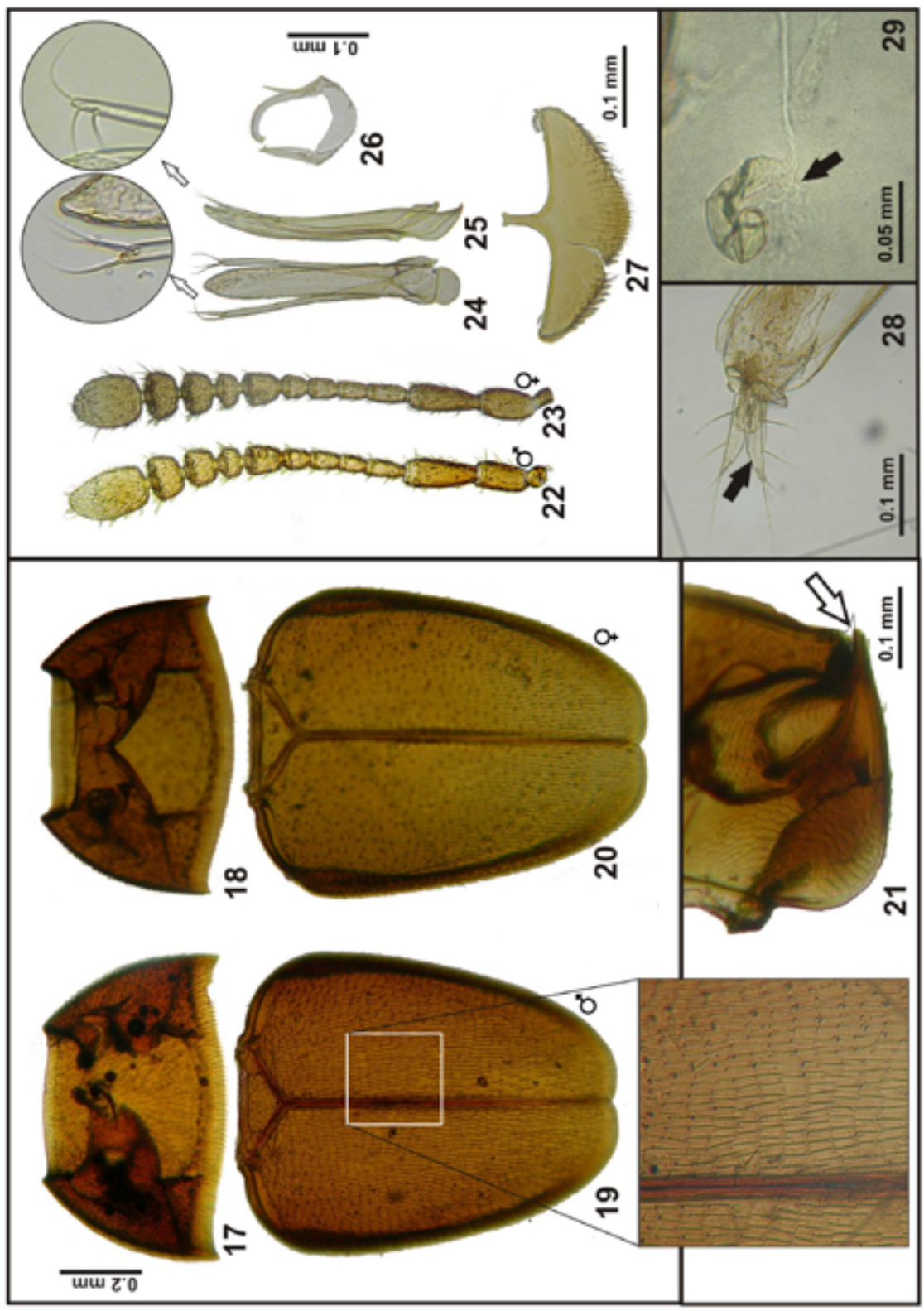

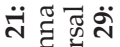

完它 客安式 त $\ddot{\tilde{~}}$ ठै. o क

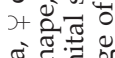

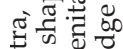
元 0 고 워 获艺完志 宊 ฮี่ ब है है क्ञ 등 중

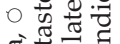
ฮ 空医定

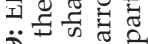
국

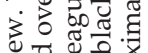
च च

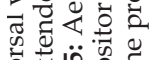
흥 붕효

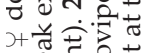

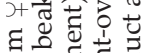
즐 든

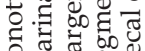
등 중 它灾 죽 럼 30. 5 \%

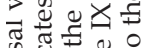

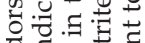
$\square \times$ च 궁 월

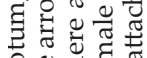
용 है 을 전 ㄴ. 훙 क 굴 고 5.5 के क जै क्त证

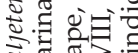
इ ฮี ฮร

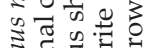
흘 है ن 궁 口

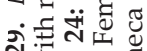

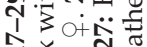
스 $\times$

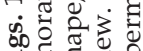

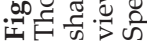




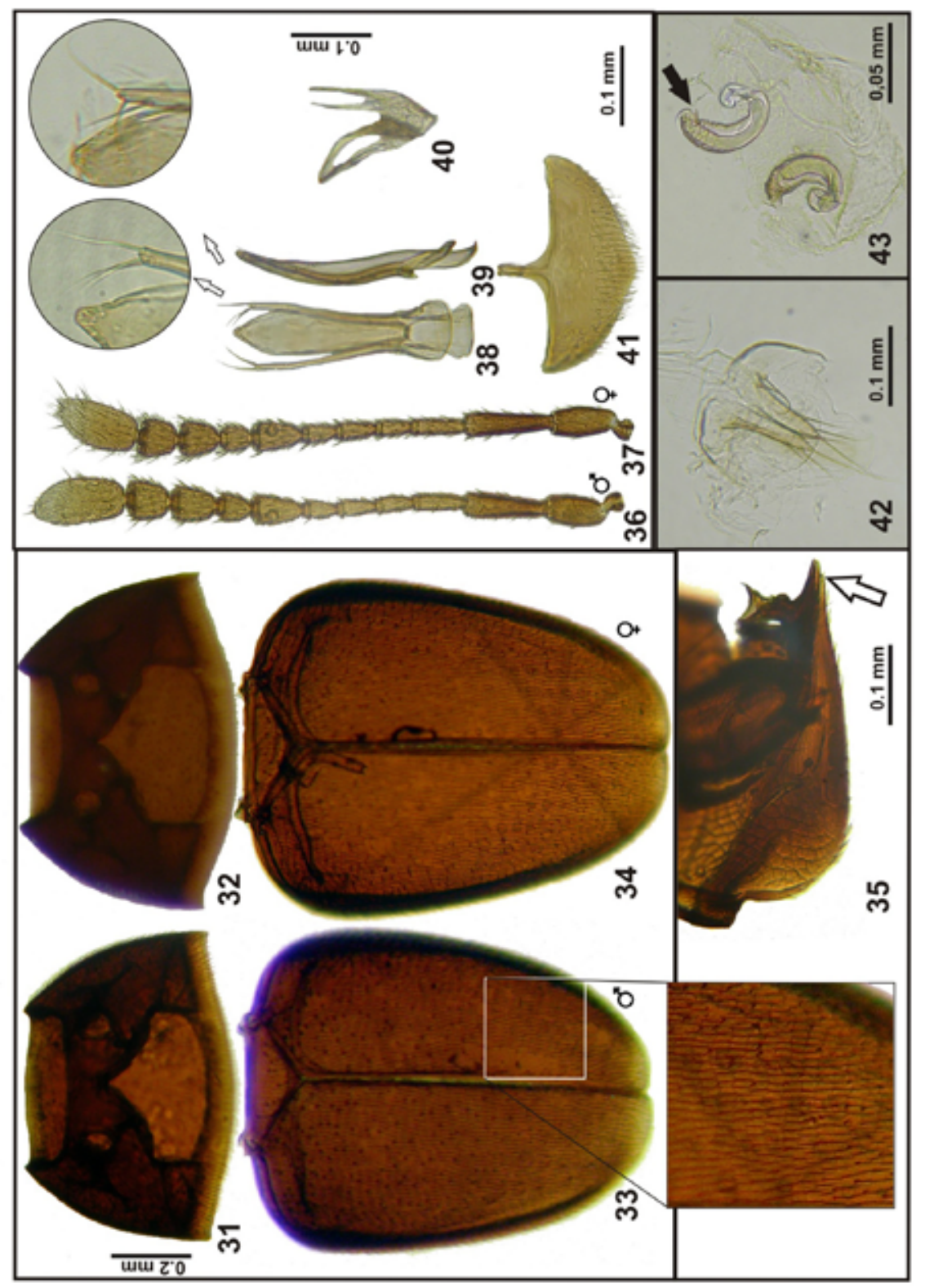

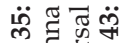

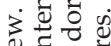
文式 तु ले छे

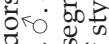
$+\stackrel{5}{0}$

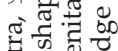
500 I

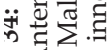
这嵌希

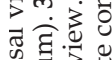
过苞苞 ० $\frac{5}{\pi} .5$

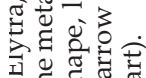
I. 正 रे क्ष उे वे 5 过

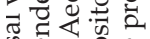
क्षे ○ 5

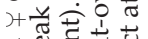
ฐ

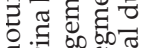

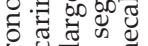

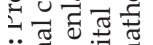
ช. उ० 음 100 क 2.0 के

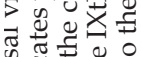

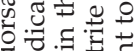
을.. E 0. हี 응 त्ञ

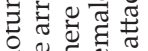
․ㅠ 단

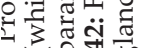
구웡 मे 3 उ ․ 5 . के कि 훙 훙

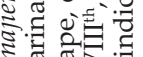
ड $\frac{\pi}{5} 3$

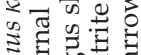
उٓ क्ष 至总这券 D. के चु ฮु अ 3 o+ क

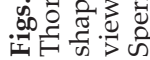




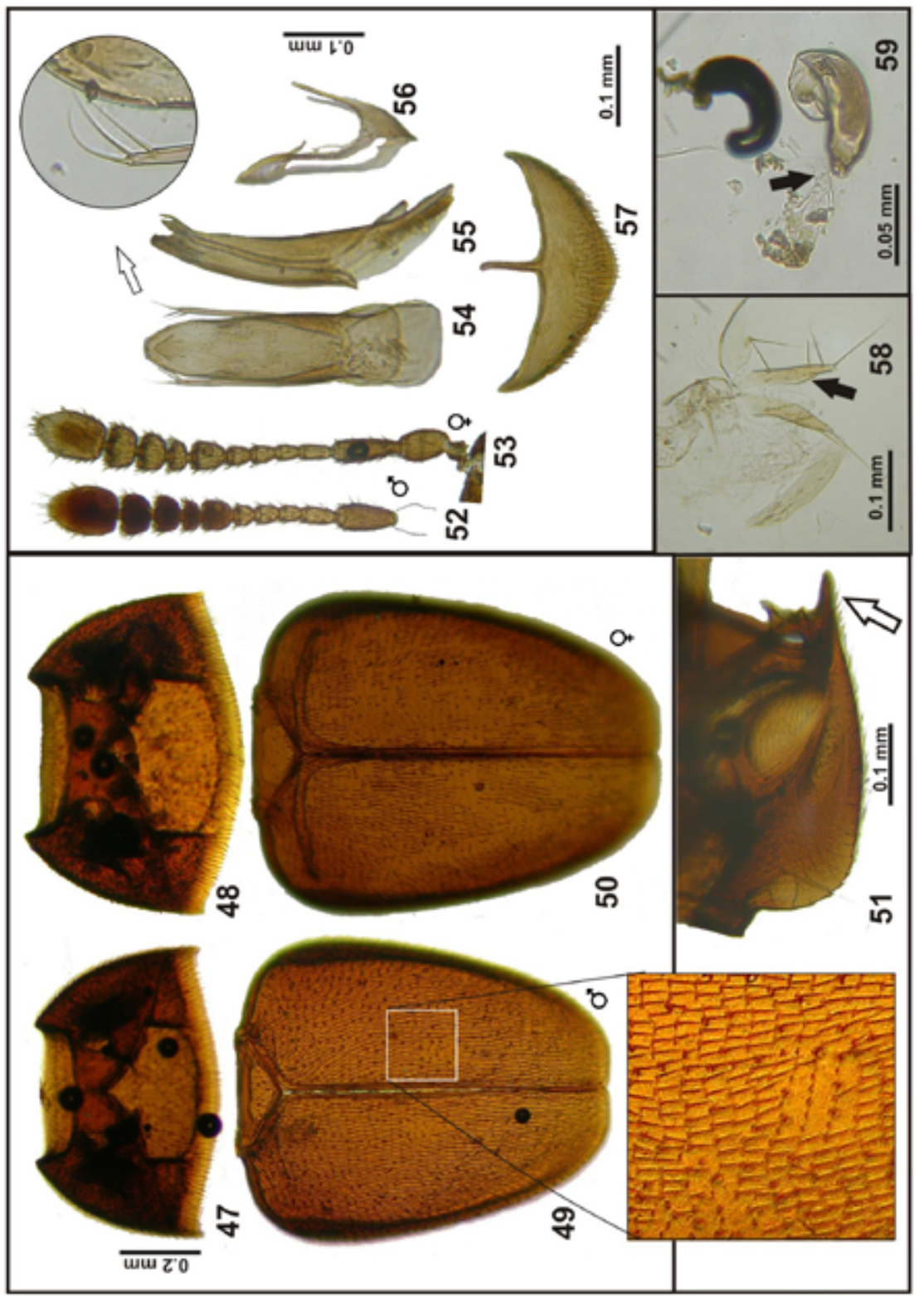

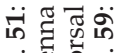

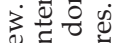
穵求

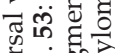

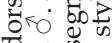

+

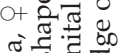

ज的

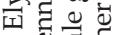

ถั

<

क्र

दิ

की

प

疎

ज记

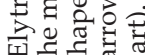

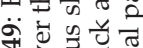

भे

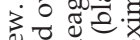

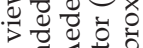

च

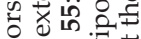

证宁

o+

है ฮี हี

릉 영

ป ฮ

즘 쥬 즈

क

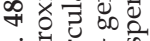

3.

过包

드웡ㅇㅇ

勿:

ธ․ㅈ

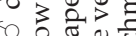

द्व

द्व

훌 점

दิ

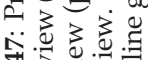

$\therefore \frac{1}{2} 5$

대유 శ]

केत्

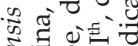

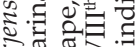

के के

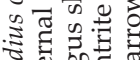

उٓ

इ के

ह

คำ मीं

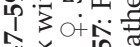

f $x$ in

我苋造密 

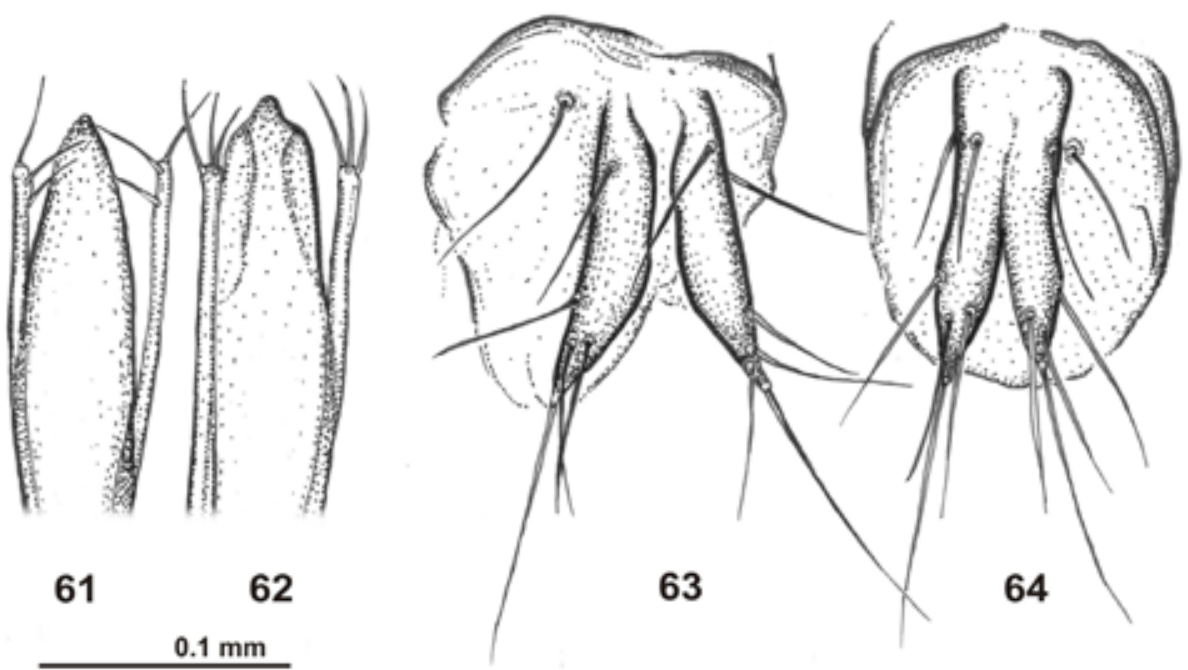

Figs. 61-62. Paramere apex with insertion of three erected setae. 61: Bathyscidius tristiculus. 62: Bathyscidius rambouseki. Figs: 63-64: Female genital segment-ovipositor. 63: Bathyscidius tristiculus. 64: Bathyscidius rambouseki.

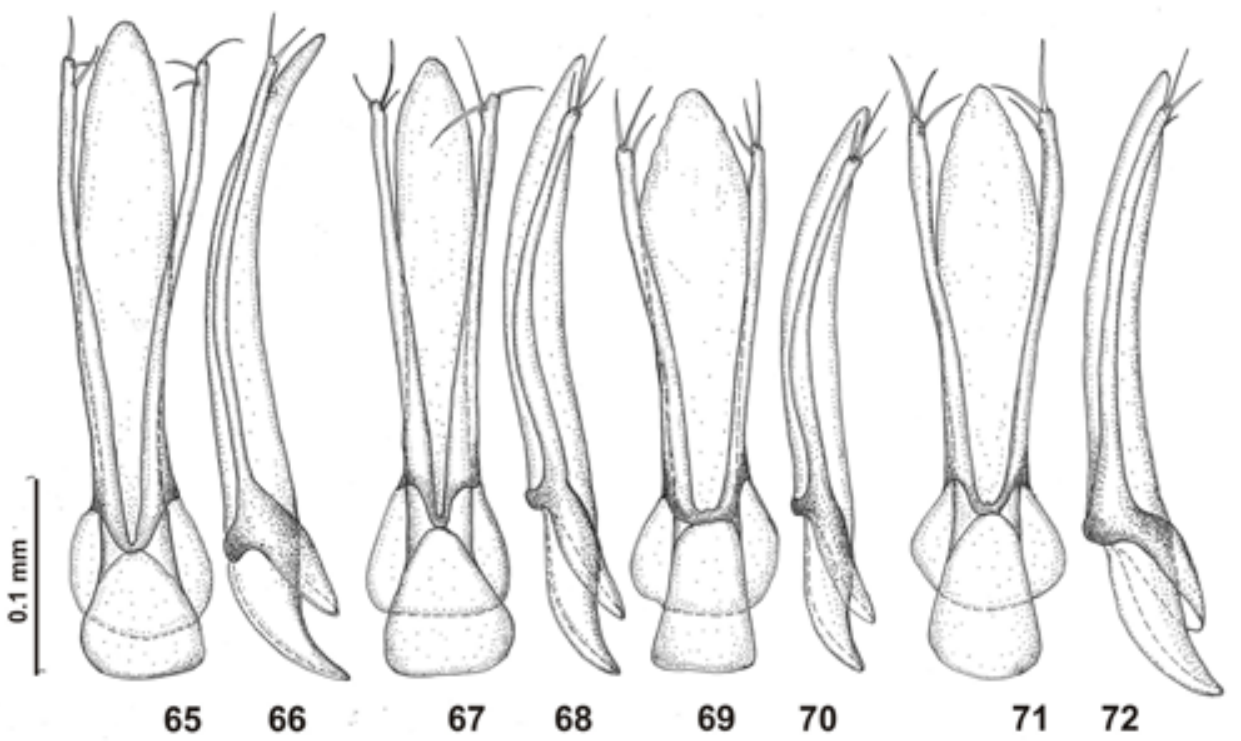

Figs. 65-72. Bathyscidius edeagus shape in dorsal and ventral view: 65: B. tristiculus, dorsal view. 66: B. tristiculus, ventral view. 67: B. mljetensis sp. n., dorsal view. 68: B. mljetensis sp. n., ventral view. 69: B. fallaciosus, dorsal view. 70: B. fallaciosus, ventral view. 71: B. komajiensis sp. n., dorsal view. 72 : $B$. komajiensis sp. n., ventral view. 


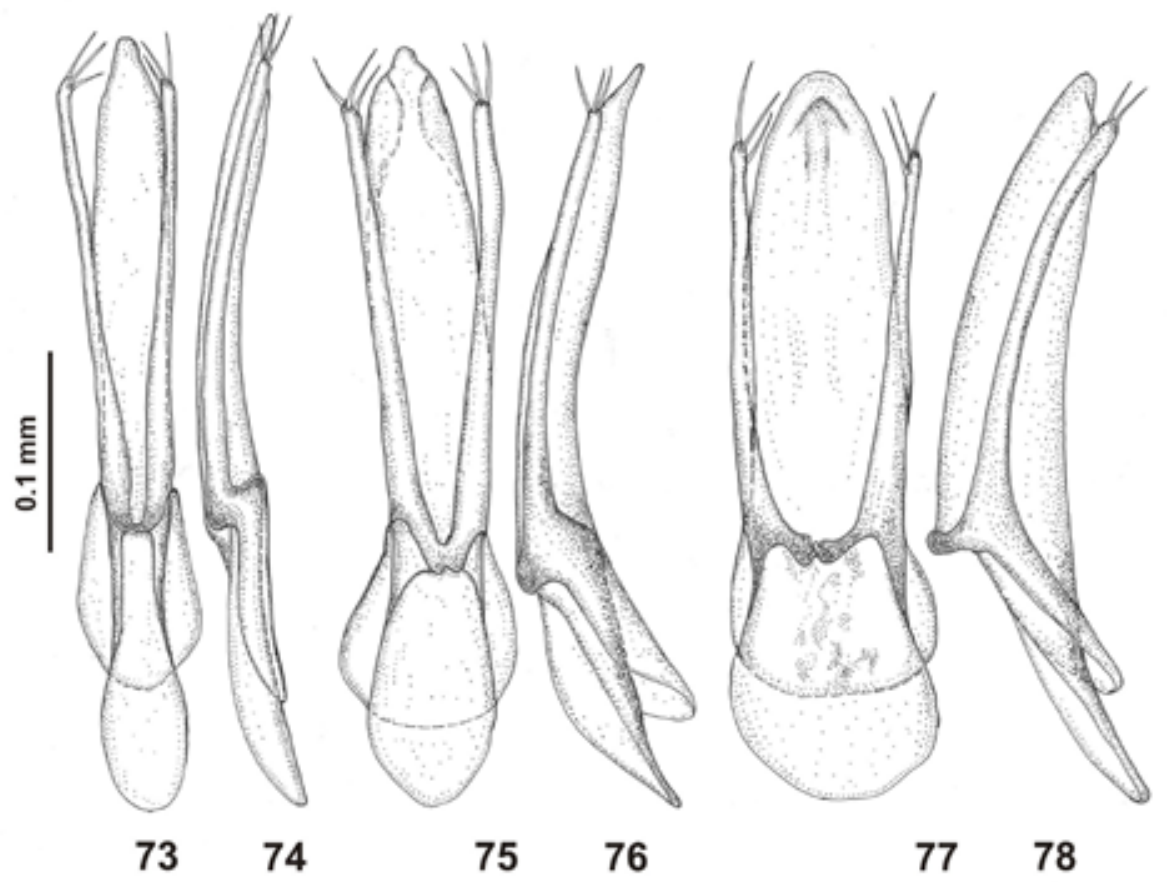

Figs. 73-78. Bathyscidius edeagus shape in dorsal and ventral view: 73: $B$. tomoricensis, dorsal view. 74: $B$. tomoricensis, ventral view. 75: B. rambouseki, dorsal view. 76: B. rambouseki, ventral view. 77: $B$. orjensis sp. n., dorsal view. 78: B. orjensis sp. n., ventral view.
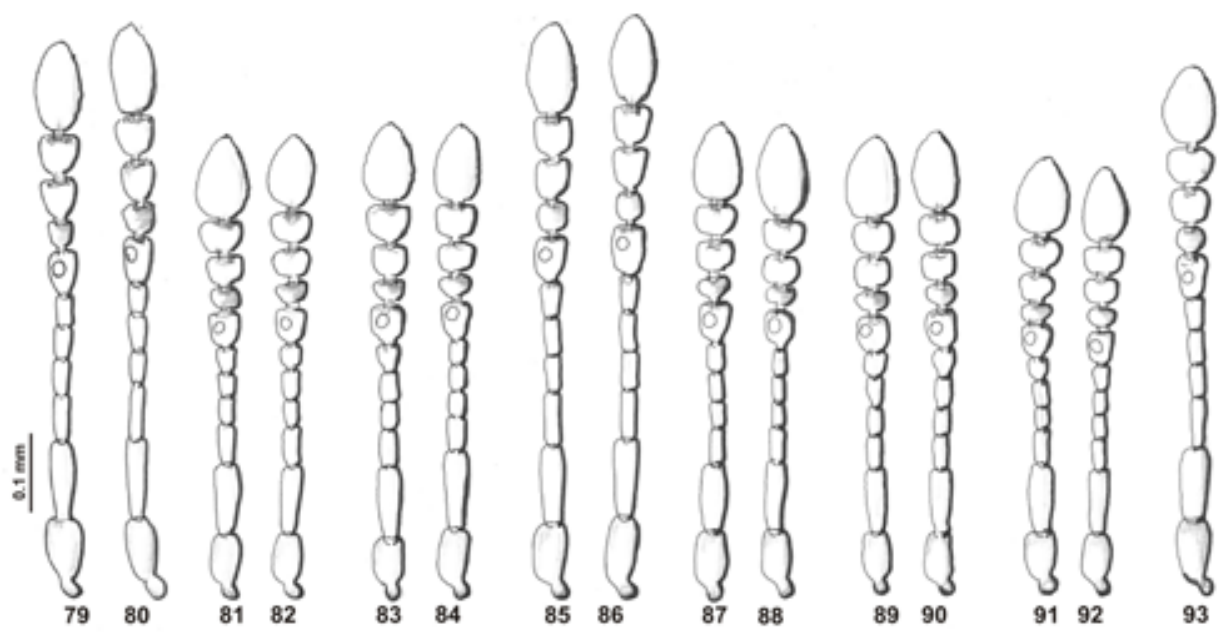

Figs. 79-93. Bathyscidius Antenna shape of males and females (in dorso-ventral view): 79: B. tristiculus, స. 80: B. tristiculus, ․ 81: B. mljetensis sp. n., ڤ. 82: B. mljetensis sp. n., ․ 83: B. fallaciosus, ô. 84: B. fallaciosus, +. 85: B. komajiensis sp. n., 8 . 86: B. komajiensis sp. n., +. 87: B. tomoricensis, O. 88: B.

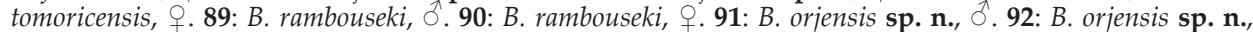
+.93: Laneyriella andrijevicensis,, . 